\title{
GPR55 regulates cannabinoid 2 receptor-mediated responses in human neutrophils
}

Nariman A B Balenga ${ }^{1}$, Elma Aflaki ${ }^{2}$, Julia Kargl ${ }^{1}$, Wolfgang Platzer ${ }^{1}$, Ralf Schröder ${ }^{3}$, Stefanie Blättermann ${ }^{3}$, Evi Kostenis ${ }^{3}$, Andrew J Brown ${ }^{4}$, Akos Heinemann ${ }^{1}$, Maria Waldhoer ${ }^{1}$

${ }^{1}$ Institute of Experimental and Clinical Pharmacology, Medical University of Graz, Universitätsplatz 4, Graz A-8010, Austria; ${ }^{2}$ Institute of Molecular Biology and Biochemistry, Medical University of Graz, Graz, Austria; ${ }^{3}$ Section Molecular, Cellular and Pharmacobiology, Institute for Pharmaceutical Biology, University of Bonn, Bonn, Germany; ${ }^{4}$ Department of Screening and Compound Profiling, GlaxoSmithKline, Medicines Research Centre, Gunnels Wood Road, Stevenage, Hertfordshire, UK

The directional migration of neutrophils towards inflammatory mediators, such as chemokines and cannabinoids, occurs via the activation of seven transmembrane $G$ protein coupled receptors (7TM/GPCRs) and is a highly organized process. A crucial role for controlling neutrophil migration has been ascribed to the cannabinoid $\mathrm{CB}_{2}$ receptor $\left(C B_{2} R\right)$, but additional modulatory sites distinct from $C B_{2} R$ have recently been suggested to impact $C B_{2} R$-mediated effector functions in neutrophils. Here, we provide evidence that the recently de-orphanized 7TM/GPCR GPR55 potently modulates $\mathrm{CB}_{2} \mathrm{R}$-mediated responses. We show that GPR55 is expressed in human blood neutrophils and its activation augments the migratory response towards the $C_{2} R$ agonist 2-arachidonoylglycerol (2-AG), while inhibiting neutrophil degranulation and reactive oxygen species (ROS) production. Using HEK293 and HL60 cell lines, along with primary neutrophils, we show that GPR55 and $C_{2} R$ interfere with each other's signaling pathways at the level of small GTPases, such as Rac2 and Cdc42. This ultimately leads to cellular polarization and efficient migration as well as abrogation of degranulation and ROS formation in neutrophils. Therefore, GPR55 limits the tissueinjuring inflammatory responses mediated by $C_{2} R$, while it synergizes with $C_{B} R$ in recruiting neutrophils to sites of inflammation.

Keywords: GPR55; $\mathrm{CB}_{2} \mathrm{R}$; chemotaxis; ROS production; Rac2; $\mathrm{Cdc} 42$

Cell Research (2011) 21:1452-1469. doi:10.1038/cr.2011.60; published online 5 April 2011

\section{Introduction}

The first line of defense against infectious agents is the innate immune system, which consists of macrophages and granulocytes $[1,2]$. Neutrophils, as the first granulocytes recruited to a site of inflammation, gain special capabilities during their maturation, i.e., the potential for efficient migration, phagocytosis and production of reactive oxygen species (ROS) and enzyme-rich granules [3]. A gradient of bacterial products (i.e., $N$-Formylmethionyl-leucyl-phenylalanine (fMLP)) [4] and media-

Correspondence: Nariman A B Balenga ${ }^{\mathrm{a}}$, Maria Waldhoer

a'E-mail: nariman.balenga@medunigraz.at

Tel: +43-316-380-4307; Fax: +43-316-380-9645

${ }^{b}$ E-mail: maria.waldhoer@medunigraz.at

Received 8 October 2010; revised 20 December 2010; accepted 12 January 2011; published online 5 April 2011 tors released by injured tissues and macrophages (i.e. complement factor 5a (C5a) [5], interleukin 8 (IL-8) [6] and endocannabinoids $[7,8]$ ) are responsible for the migration of neutrophils to a site of inflammation and their consequent activation. Of these, endocannabinoids, such as anandamide and 2-arachidonoylglycerol (2-AG), are produced by macrophages and have long been regarded as immune modulators [7].

The cannabinoid 2 receptor $\left(\mathrm{CB}_{2} \mathrm{R}\right)$ is mainly expressed in hematopoietic cells and belongs to the 7 transmembrane (7TM) G protein coupled receptor (GPCR) family $[9,10]$. The $2-\mathrm{AG}$ is reported to be the main endogenous $\mathrm{CB}_{2} \mathrm{R}$ agonist [11], which induces its coupling to inhibitory $\mathrm{G} \alpha_{i}$ proteins and consequently activates extracellular signal-regulated kinases (ERK) $[12,13]$, in addition to Rac small GTPases [14]. Recently, GPR55 has been suggested as a novel putative cannabinoid receptor with a broad expression profile in a variety of tis- 
sues, including spleen and microglia cells [15-17]. The stimulation of GPR55 initiates a plethora of signaling cascades, whereby a main pathway involves $\mathrm{G} \alpha_{13}$, RhoA small GTPase, phospholipase C (PLC) and the induction of a prolonged oscillatory intracellular $\mathrm{Ca}^{2+}$ release $[15,18]$, among others [16]. Studies performed in human embryonic kidney (HEK293) cells revealed substantial controversies regarding ligands for GPR55. While anandamide [15], 2-AG [15] and $\Delta^{9}$-tetrahydrocannabinol $\left(\Delta^{9}\right.$ THC) $[15,19]$ were reported to have agonist properties on GPR55, other studies showed no activity of these cannabinoids on GPR55 $[18,20]$. We and others have previously discovered that some of the cannabinoid 1 receptor $\left(\mathrm{CB}_{1} \mathrm{R}\right)$ antagonists and inverse agonists, i.e., AM251 and SR141716A (rimonabant) act as agonists on GPR55 $[18,20,21]$. In addition, lysophosphatidylinositol (LPI) was shown to be an endogenous agonist for this receptor $[22,23]$. LPI, as one of the intermediary compounds in the synthetic pathway of 2-AG [24], was found to be secreted by fibroblasts [25] and epithelial cancer cells [26] at high concentrations up to $30 \mu \mathrm{M}$ and showed mitogenic effects [25].

The level of endocannabinoids produced by immune cells is increased during inflammatory conditions [27]. LPS-stimulated rat or mouse macrophages produced high amounts of anandamide and 2-AG, respectively [7, 28]. Furthermore, addition of the $E$. coli lipid X (a derivative of LPS) to the mouse macrophage cell line RAW 264.7 induced a 4-8-fold increase in the levels of LPI [29]. In addition, mouse peritoneal macrophages stimulated with zymosan produced and secreted large amounts of LPI via the rapid degradation of phosphatidylinositol [30]. However, there have been some discrepancies regarding the role of cannabinoids in mediating the trafficking of immune cells, especially neutrophils. For instance, the activation of $\mathrm{CB}_{2} \mathrm{R}$ by $2-\mathrm{AG}$ did not induce polarization and migration of human blood neutrophils [14]. However, pretreatment of neutrophils with 2-AG inhibited the fMLP- and IL-8-induced migration without affecting the polarization of the cells [14]. In contrast, a recent study showed that 2-AG does not inhibit migration of human neutrophils towards fMLP and does not show chemotactic effects by itself [31]. Moreover, $\Delta^{9}$-THC, the major psychoactive component of Cannabis sativa, inhibited monocyte chemoattractant protein-1-induced migration in macrophages [32]. In contrast, 2-AG was shown to be an efficient chemoattractant for the myeloid cell line NFS [33], mouse neopallia microglial cells [34] and EoL-1 human eosinophilic leukemia cells [35].

The directional migration of neutrophils towards chemoattractants is a highly organized process. The coordinated interaction of neutrophilic cell surface molecules with vascular endothelial cells is typically accompanied by a regulated rearrangement of the cytoskeleton of neutrophils [36]. The latter is mainly governed by members of the Rho family GTPases including RhoA, Rac1 and Cdc42 [37]. Other functions of neutrophils, i.e., degranulation and ROS production, are also under the control of these GTPases, i.e., mainly RhoA and Rac2 [38, 39]. It has been previously demonstrated that $2-\mathrm{AG}$ inhibited chemokine-induced migration of human neutrophils and neutrophil-like HL60 cells via a $\mathrm{CB}_{2} \mathrm{R}$-mediated inhibition of RhoA activity [14]. Another recent study suggested that cannabinoids may modulate the function of neutrophils at a site distinct from $\mathrm{CB}_{2} \mathrm{R}$ and $\mathrm{CB}_{1} \mathrm{R}$ [31].

Here we suggest that GPR55 is involved in the regulation of human neutrophil responses to cannabinoids. We show that GPR55 is expressed in neutrophils and that there is a crosstalk between GPR55 and $\mathrm{CB}_{2} \mathrm{R}$ at the level of Rho small GTPases. This interplay culminates in efficient migration of neutrophils, while inhibiting effector functions of neutrophils, such as degranulation and respiratory burst.

\section{Results}

Chemotaxis and polarization of neutrophils are dependent on the gradient of GPR55 and $C B_{2} R$ agonists

It has previously been suggested that there is a site distinct from $C_{1} R$ and $C_{2} R$, which affects $C_{2} R$ mediated migration in human blood neutrophils and that this site could be GPR55 [31]. In addition, another recent study showed that the highly metastatic MDA-MB231 breast cancer cell line expresses GPR55 and migrates efficiently towards LPI [40]. Therefore, we set out to determine the effects of LPI on the migration of neutrophils. As Figure 1Ai shows, neutrophils readily migrated towards a gradient of LPI (Figure 1Ai, - ). Likewise, the more stable synthetic cannabinoid GPR55 agonist and $\mathrm{CB}_{1} \mathrm{R}$ antagonist AM251 [21] induced a concentrationdependent migration of neutrophils (Figure 1Ai, •). The chemotactic properties of these ligands were comparable to that of the $\mathrm{CB}_{2} \mathrm{R}$ agonist 2-AG (Figure 1Ai, $\downarrow$ ). Next, we tested whether the migration of neutrophils towards either LPI or 2-AG could be blocked by pretreating the cells with selective receptor antagonists. Pre-incubation of neutrophils with either the GPR55 antagonist cannabidiol $(5 \mu \mathrm{M})$ [41] (Figure 1Aii, CBD) or the selective $\mathrm{CB}_{2} \mathrm{R}$ antagonist AM630 (Figure 1Aii, $5 \mu \mathrm{M}$ ) for 10 min significantly diminished the migratory properties of neutrophils towards LPI $(3 \mu \mathrm{M})$ or 2 -AG $(1 \mu \mathrm{M})$, respectively. In contrast, neutrophil migration was not impaired when cells were pretreated with the 'wrong' antagonists, i.e., $5 \mu \mathrm{M}$ of $\mathrm{CBD}$ followed by $1 \mu \mathrm{M} 2-\mathrm{AG}$ stimulation 


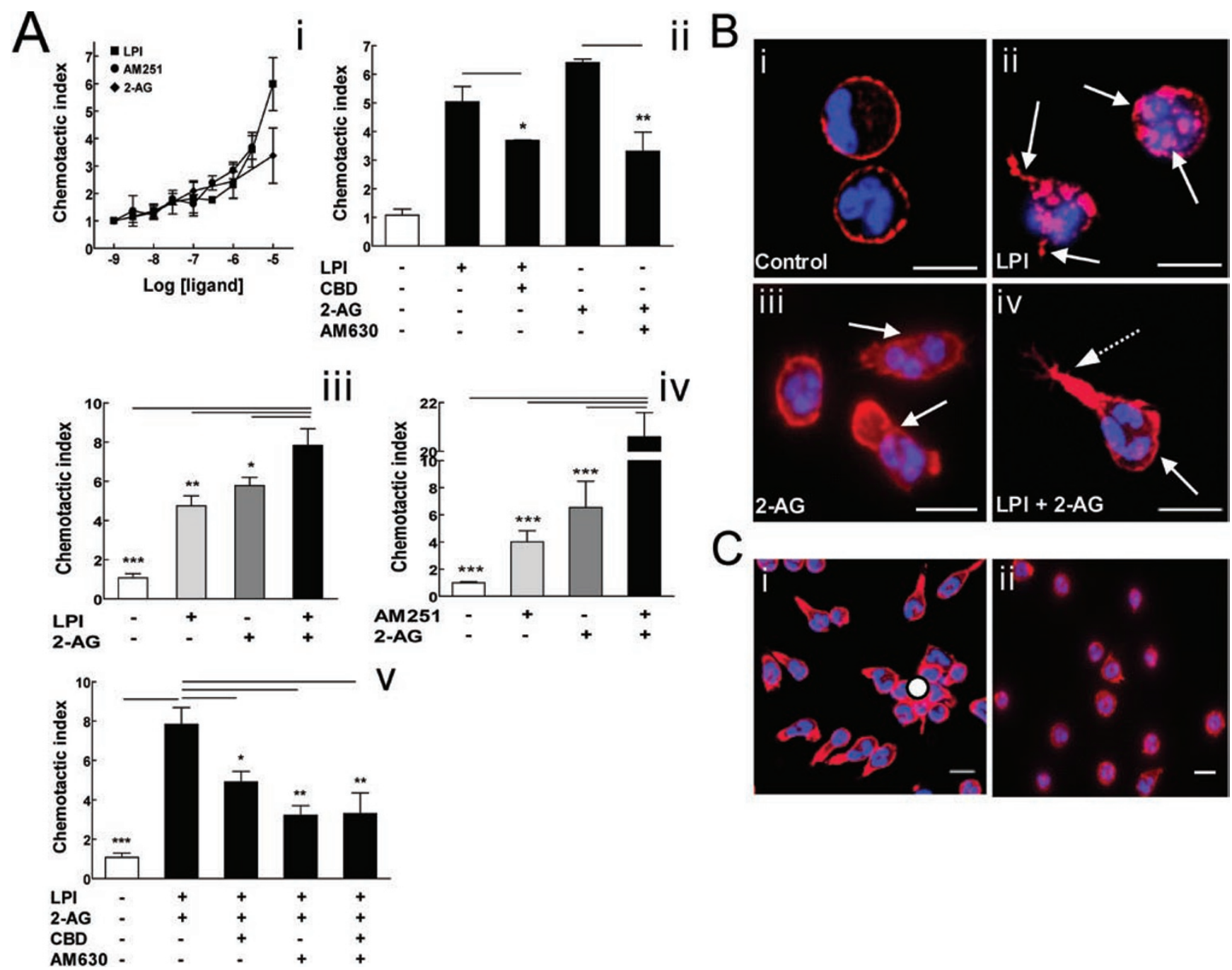

Figure $1 \mathrm{GPR} 55$ and $\mathrm{CB}_{2} \mathrm{R}$ agonists induce the directional migration and polarization of neutrophils. (A) Human blood neutrophils were placed to the upper wells of a microBoyden chamber and (i) were allowed to migrate towards increasing concentrations of LPI (घ), AM251 (•) or 2-AG $(\bullet)$ in the bottom wells for $1 \mathrm{~h}$. Migrated cells in the bottom wells were counted by a flow cytometer. (ii) Neutrophils were pre-incubated with DMSO $(0.05 \%)$, CBD $(5 \mu \mathrm{M})$ or AM630 $(5 \mu \mathrm{M})$ for $10 \mathrm{~min}$ at $37^{\circ} \mathrm{C}$ and their migration towards LPI $(3 \mu \mathrm{M})$ or 2-AG $(1 \mu \mathrm{M})$ was assessed as in panel Ai. (iii) Chemotaxis of neutrophils towards DMSO $(0.01 \%$, white bar), LPI (3 $\mu \mathrm{M}$, light gray bar), 2-AG (1 $\mu \mathrm{M}$, dark gray bar) or LPI and 2-AG combined $(3 \mu \mathrm{M}$ and $1 \mu \mathrm{M}$, respectively, black bar) was assessed as in panel Ai. (iv) Chemotaxis of neutrophils was assessed as in panel iii, except that AM251 (3 $\mu \mathrm{M})$ was used instead of LPI. (v) Neutrophils were pre-incubated with DMSO (0.05\%), CBD (5 $\mu$ M) and/or AM630 $(5 \mu \mathrm{M})$ for $10 \mathrm{~min}$ at $37{ }^{\circ} \mathrm{C}$ and their migration towards DMSO $(0.01 \%)$ and LPI $(3 \mu \mathrm{M})+2-\mathrm{AG}(1 \mu \mathrm{M})$ was assessed as in panel Ai. Representatives of 3-6 independent experiments, performed in quadruplicates, are shown for all subpanels. Data are mean \pm SEM $\left({ }^{*} P<0.05 ;{ }^{* *} P<0.01 ;{ }^{* * *} P<0.001\right)$. (B) Neutrophils were seeded on fibronectin-coated glass coverslips and treated with a gradient of $0.01 \%$ DMSO (control; i) or ligands for $5 \mathrm{~min}$ at $37^{\circ} \mathrm{C}$ and stained with methanolic Texas-Red Phalloidin (red) and DAPI (blue). (ii) LPI treatment $(3 \mu \mathrm{M})$ induced fuzzy protrusions (arrows), whereas (iii) $2-\mathrm{AG}(1 \mu \mathrm{M})$ induced an elongation of the neutrophils (arrows). (iv) Extending head (arrow) and tail formation (dashed arrow) indicate a polarization of neutrophils in response to a mixture of LPI $(3 \mu \mathrm{M})$ and 2-AG $(1 \mu \mathrm{M})$. Cells were analyzed using a Zeiss LSM510 META Axioplan confocal microscope (original magnification: 100x). Scale bars: $10 \mu \mathrm{m}$. Representative images of three independent experiments are shown. (C) Neutrophils were seeded on fibronectin-coated glass coverslips and treated with LPI ( $3 \mu \mathrm{M})$ and 2-AG $(1 \mu \mathrm{M})$ for $5 \mathrm{~min}$ at $37^{\circ} \mathrm{C}$ and stained with Texas-Red Phalloidin (red) and DAPI (blue). (i) Cells displayed a clear directional and polarized structure when migrating towards a local source of LPI/2-AG (white dot). (ii) In contrast, no cytoskeleton remodeling occurred after a uniform addition of agonists to the medium. Cells were analyzed as in panel B (original magnification: 63×). Representative images of three independent experiments are shown. Scale bars: $10 \mu \mathrm{m}$. 
or $5 \mu \mathrm{M}$ AM630 followed by $3 \mu \mathrm{M}$ LPI stimulation, respectively (data not shown).

In most of the previous studies, 2-AG has been used alone $[12,35]$ or in combination with chemokines to induce neutrophil migration $[14,42]$. Since both $2-A G$ and LPI are endogenous lipid mediators released by stimulated macrophages [7, 29, 30, 43], we investigated the concomitant effect of 2-AG and LPI on the migration of neutrophils. The combination of LPI $(3 \mu \mathrm{M})$ and 2-AG $(1 \mu \mathrm{M})$ showed a significant impact on neutrophil migration, when compared to LPI or 2-AG alone (Figure 1Aiii). More prominently, the migration of neutrophils towards AM251 $(3 \mu \mathrm{M})$, when combined with 2-AG (1 $\mu \mathrm{M})$, was synergistically enhanced compared to neutrophils migrating towards AM251 or 2-AG alone (Figure 1Aiv). These effects could be significantly diminished by pretreating the cells with the GPR55 antagonist CBD (5 $\mu \mathrm{M})$, the $\mathrm{CB}_{2} \mathrm{R}$ antagonist AM630 $(5 \mu \mathrm{M})$ or a combina- tion of both for 10 min (Figure 1Av).

In response to chemokines, neutrophils undergo cytoskeletal rearrangement and shape change, which culminates in cellular polarization and thereby enables the cells to migrate efficiently [44]. We hence next assessed the cytoskeletal rearrangement of neutrophils in response to a 5-min exposure to a gradient of LPI or 2-AG alone, or a gradient of their combination thereof. Cytoskeletal rearrangement was assessed by $\mathrm{F}$-actin phalloidin staining. In neutrophils treated with vehicle, actin was found at the periphery of the cells, which had a round spherical shape (Figure 1Bi). LPI $(3 \mu \mathrm{M})$ induced random nondirectional protrusions in the neutrophils (Figure 1Bii, arrows). Consistent with previous reports [14], treatment of neutrophils with 2-AG $(1 \mu \mathrm{M})$ resulted in an elongation of cells, however, without showing the characteristic polarity of migrating leukocytes (Figure 1Biii, arrows). Only when neutrophils were concomitantly incubated

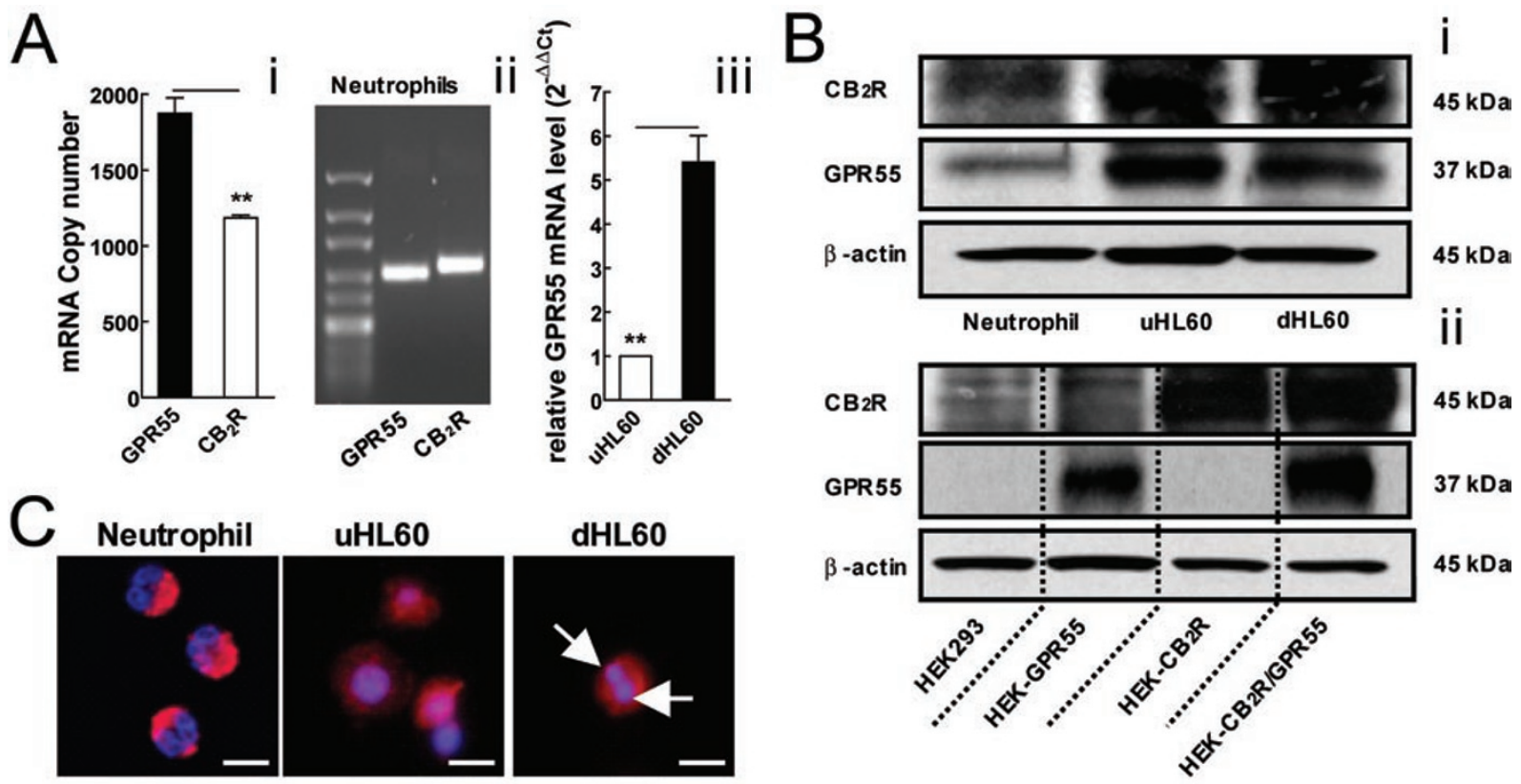

Figure 2 GPR55 is highly expressed in human blood neutrophils and neutrophil-like HL60 cells. (A) GPR55 and CB ${ }_{2} R$ mRNA expression in freshly isolated human blood neutrophils was assessed by (i) quantitative real-time PCR and (ii) RT-PCR. PCR products were analyzed on a 3\% agarose gel. (iii) Relative expression of GPR55 mRNA in undifferentiated (uHL60) and HL60 cells differentiated with $1.75 \%$ DMSO for 4 days (dHL60) was measured by real-time PCR. Representatives of three independent experiments are shown for all subpanels. Data are mean \pm SEM ( ${ }^{* *} P<0.01$ ). (B) (i) GPR55 and $\mathrm{CB}_{2} \mathrm{R}$ protein expression in neutrophils, UHL60 and dHL60 cells was assessed by western blotting using rat anti-GPR55 and rabbit anti-CB ${ }_{2} \mathrm{R}$ antibodies. Lysates were probed for $\beta$-actin as a loading control. A representative blot of three independent experiments is shown. (ii) Western blotting of GPR55 and $\mathrm{CB}_{2} \mathrm{R}$ in lysates from HEK293, HEK-GPR55, HEK-CB ${ }_{2} \mathrm{R}$ and HEK-CB ${ }_{2}$ /GPR55 cells was performed as in panel $\mathrm{Bi}$. A representative blot of three independent experiments is shown. (C) GPR55 expression in human blood neutrophils, UHL60 and dHL60 cells was confirmed with the rat anti-GPR55 antibody (1:250) and an Alexa Fluor-594 goat anti-rat secondary antibody (1:250). The dHL60 cells show multilobular nuclei (arrows). Cells were analyzed using a Zeiss LSM510 META Axioplan confocal microscope (original magnification: 100x). Scale bars: $10 \mu \mathrm{m}$. Representative images of 2-3 independent experiments are shown. 
with a gradient of LPI $(3 \mu \mathrm{M})$ and 2 -AG $(1 \mu \mathrm{M})$, the typical polarity of migrating neutrophils - i.e. extending head (arrow) and retracting tail (dashed arrow) could be detected (Figure 1Biv). This effect was not due to the higher concentration of the combined ligands per se, since neither LPI nor 2-AG alone, up to $5 \mu \mathrm{M}$, could evoke the same cytoskeletal rearrangement (data not shown), but it was dependent on the gradient of compounds (see Figure 1C).

When LPI $(3 \mu \mathrm{M})$ and 2-AG $(1 \mu \mathrm{M})$ were simultaneously applied to the media using the top of a narrow tip (Figure 1Ci, white dot), a directional movement towards the source of ligands was observed. The uniform addition of ligands into the culture medium, however, did not evoke any shape change in the neutrophils (Figure 1Cii). Likewise, when tested in a Boyden-migration assay, no migration of neutrophils could be observed in the absence of a ligand gradient (Supplementary information, Figure S1).

Taken together, these data show that LPI, AM251 or 2-AG alone could each evoke neutrophil migration albeit to a lesser extent than when used in combination - and without inducing the typical morphology of migrating neutrophils. In fact, only the combination of LPI and 2-AG evoked a strong migratory response in human blood neutrophils via the establishment of a rear-front asymmetric morphology.

\section{GPR55 is expressed in human blood neutrophils}

Next, we investigated the expression of the cannabinoid receptors $\mathrm{CB}_{1}$ and $\mathrm{CB}_{2}$ as well as that of GPR55 in human blood neutrophils at both mRNA and protein levels. It has previously been reported that the pattern of expression levels of $\mathrm{CB}_{1}$ and $\mathrm{CB}_{2}$ receptors in neutrophils depends on the isolation procedure [45-47]. Here we used an untouched, non-column based system at room temperature in the absence of $\mathrm{Ca}^{2+}$ and $\mathrm{Mg}^{2+}$ ions to prevent a stimulation of the cells. GPR55 mRNA copy numbers (Figure 2Ai, black bar) were significantly higher than those of the $\mathrm{CB}_{2} \mathrm{R}$ (Figure 2Ai, white bar). Indeed, both $\mathrm{CB}_{2} \mathrm{R}$ and GPR55 mRNA could also be detected by RT-PCR (Figure 2Aii). The expression of $\mathrm{CB}_{1} \mathrm{R}$ was not detectable in either RT-PCR or real time PCR (data not shown). In addition, we tested the expression of GPR55 in differentiated neutrophil-like HL60 cells (dHL60), which expressed the differentiation marker CD11b at levels comparable to those of neutrophils (Supplementary information, Figure S2). Real time PCR analysis showed a 5.5-fold increase in GPR55 mRNA levels in dHL60 cells (Figure 2Aiii, black bar) compared to undifferentiated HL60 cells (uHL60) (Figure 2Aiii, white bar).

We next assessed the protein levels and cellular ex- pression of both GPR55 and $\mathrm{CB}_{2}$ receptors in neutrophils, as well as in uHL60 and dHL60 cells. HEK293 cell lines stably expressing the $\mathrm{CB}_{2}$ receptor (HEK$\mathrm{CB}_{2} \mathrm{R}$ ), the GPR55 receptor (HEK-GPR55) [18] alone or in combination with the $\mathrm{CB}_{2}$ receptor $\left(\mathrm{HEK}-\mathrm{CB}_{2} \mathrm{R} /\right.$ GPR55) served as controls. Using antibodies specifically targeting the respective receptors, we found that GPR55 and $\mathrm{CB}_{2} \mathrm{R}$ proteins were expressed in neutrophils, uHL60 and AHL60 cells at the appropriate protein sizes (Figure $2 \mathrm{Bi}, \sim 37 \mathrm{kDa}$ for GPR55 and $\sim 45 \mathrm{kDa}$ for $\mathrm{CB}_{2} \mathrm{R}$ ). The specificity of the antibodies was confirmed by western blot using the lysates from HEK293, HEK-GPR55, HEK-CB ${ }_{2}$ and HEK-CB 2 R/GPR55 cells. As Figure 2Bii shows, the antibodies reacted with their respective targets only. Moreover, we confirmed the expression of GPR55 in freshly isolated neutrophils and HL60 cells by immunofluorescence using the rat anti-GPR55 antibody (Figure 2C). As observed in other primary cells [48], GPR55 was predominantly found intracellulary in both neutrophils and HL60 cells. This staining was specific, since only HEK-GPR55 cells, but not untransfected HEK293 cells showed a positive immunoreactivity with the rat antiGPR55 antibody (Supplementary information, Figure S3).

$G \alpha_{13} /$ RhoA and $G \alpha_{i}$ mediate GPR55 and $C B_{2} R$ cytoskeletal remodeling/chemotactic effects, respectively

It has been demonstrated that GPR55 mediates its downstream signaling events via $\mathrm{G \alpha}_{13}$ and the RhoA small GTPase in HEK293 cells $[15,18,19]$. In addition, we recently showed that - among all Ga subunits - GPR55 couples solely to $\mathrm{G \alpha}_{13}$ in HEK293 cells [49]. In order to test which $\mathrm{G} \alpha$ protein subunits are involved in the GPR55 and $\mathrm{CB}_{2} \mathrm{R}$ mediated signaling effects in neutrophils, we used the toxins $\mathrm{C} 3$ and pertussis toxin to inhibit the activity of $\mathrm{G \alpha}_{13} / \mathrm{RhoA}$ and $\mathrm{G} \alpha_{i}$, respectively. Pre-incubation of neutrophils with $\mathrm{C} 3$ toxin $(3 \mu \mathrm{g} / \mathrm{ml}, 2$ h) significantly inhibited the LPI-induced migration of neutrophils, but showed no effect on the 2-AG-stimulated migration (Figure 3Ai and 3Aii). On the other hand, pertussis toxin $(3 \mu \mathrm{g} / \mathrm{ml}, 2 \mathrm{~h})$ prevented the migration of neutrophils towards 2-AG, but had no significant effect on LPI-induced migration (Figure 3Ai and 3Aii). Furthermore, migration of neutrophils towards a combination of LPI and 2-AG was significantly inhibited when the cells were pre-incubated with either $\mathrm{C} 3$ or pertussis toxin (Figure 3Aiii).

Next, we tested whether the impact of these inhibitors on neutrophil migration was due to an impairment of cytoskeletal remodeling. $\mathrm{C} 3$ toxin $(3 \mu \mathrm{g} / \mathrm{ml}, 2 \mathrm{~h})$ inhibited the formation of protrusions induced by LPI (compare Figure 3Bvi and 3Bii), but had no effect on the elongated morphology of 2-AG-treated neutrophils (compare 

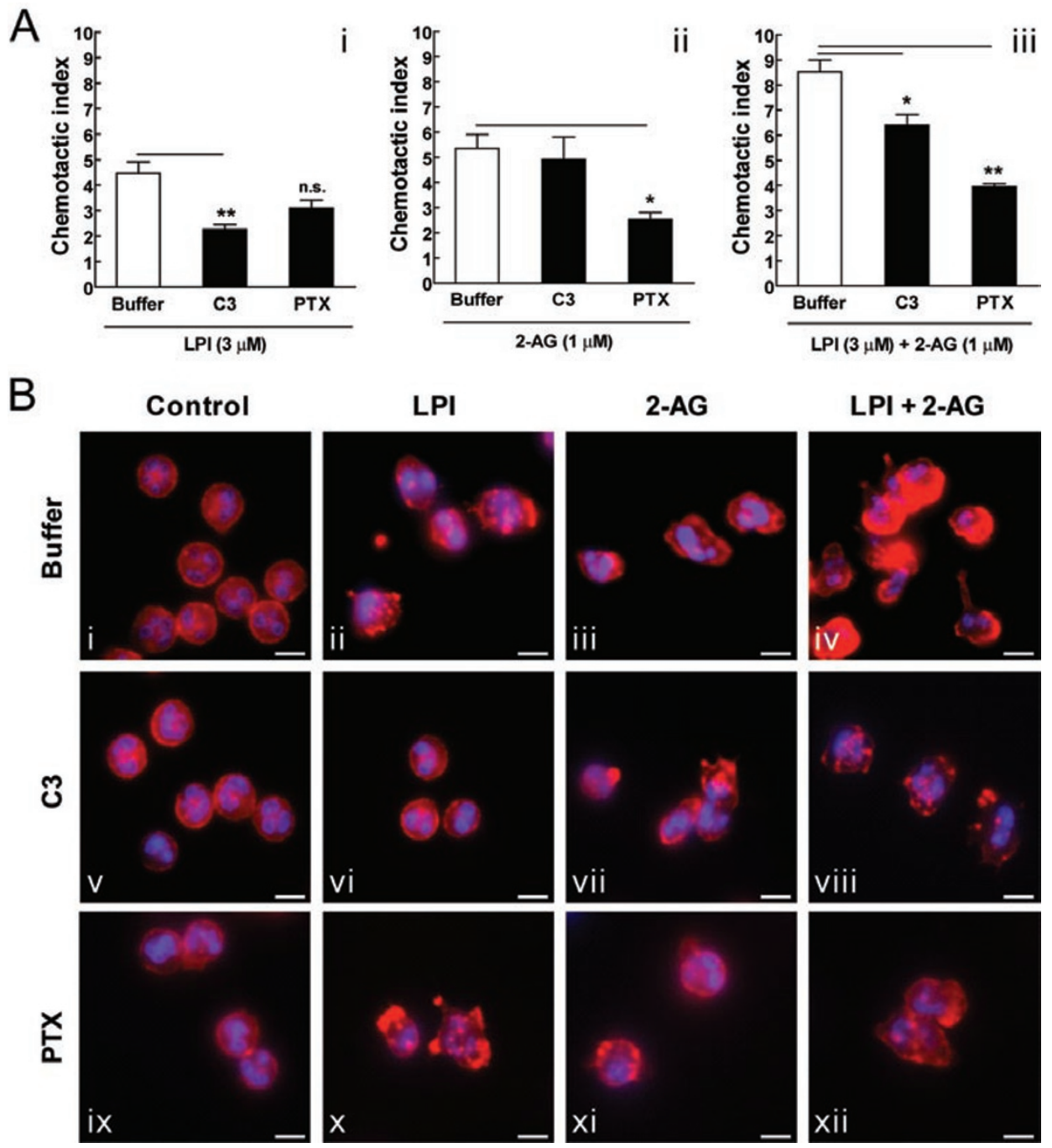

Figure 3 GPR55 and $\mathrm{CB}_{2} \mathrm{R}$ mediate chemotaxis and cytoskeletal remodeling via coupling to $\mathrm{G} \alpha_{13} / \mathrm{RhoA}$ and $\mathrm{G} \alpha_{i}$ proteins. Neutrophils were pre-incubated with cell-permeable $\mathrm{C} 3$ toxin $(\mathrm{C} 3,3 \mu \mathrm{g} / \mathrm{ml})$ or pertussis toxin $(\mathrm{PTX}, 3 \mu \mathrm{g} / \mathrm{ml}) \mathrm{for} 2 \mathrm{~h}$ at $37^{\circ} \mathrm{C}$ in PBG buffer. (A) Cells were allowed to migrate towards (i) LPI ( $3 \mu \mathrm{M})$, (ii) 2-AG (1 $\mu \mathrm{M})$ or (iii) a combination of LPI (3 $\mu \mathrm{M})$ and 2-AG $(1 \mu \mathrm{M})$ for $1 \mathrm{~h}$. Migrated cells in the bottom wells were counted by a flow cytometer. The chemotactic index was calculated as number of cells migrated towards agonists divided by the number of cells migrated towards vehicle (DMSO $0.01 \%$ ). Representatives of two independent experiments, performed in quadruplicates, are shown. Data are mean \pm SEM $\left({ }^{*} P<0.05\right.$; $\left.{ }^{* *} P<0.01\right)$. n.s.: not significant. (B) Cells were seeded on fibronectin-coated glass coverslips and treated with $0.01 \%$ DMSO (Control), LPI $(3 \mu \mathrm{M}), 2-A G(1 \mu \mathrm{M})$ or a mixture of LPI $(3 \mu \mathrm{M})$ and 2-AG $(1 \mu \mathrm{M})$ for 5 min at $37^{\circ} \mathrm{C}$ and stained with Texas-Red Phalloidin (red) and DAPI (blue). Cells were analyzed using an OLYMPUS fluorescence microscope equipped with a Hamamatsu ORCA CCD camera (original magnification: 60×). Scale bars: $10 \mu \mathrm{m}$. Representative images from 2 independent experiments are shown.

Figure 3Bvii and 3Biii). Moreover, inhibition of RhoA prevented the polarization of neutrophils in response to a combination of LPI and 2-AG (compare Figure 3Bviii and 3Biv). Pertussis toxin $(3 \mu \mathrm{g} / \mathrm{ml}, 2 \mathrm{~h})$ inhibited the elongation of 2-AG-stimulated cells (compare Figure 3Bxi and 3Biii), but did not affect the non-directional protrusions stimulated by LPI (compare Figure $3 \mathrm{Bx}$ and 3Bii). Inhibition of $\mathrm{G} \alpha_{i}$ signaling abrogated the polarized head/tail morphology of neutrophils upon treatment with a combination of LPI and 2-AG (compare Figure 3Bxii and 3Biv).

In summary, the exclusive inhibitory effects either (i) of C3 toxin on GPR55-mediated responses or (ii) of pertussis toxin on $\mathrm{CB}_{2} \mathrm{R}$-mediated responses, provide evidence for the involvement of $\mathrm{G \alpha}_{13} / \mathrm{RhoA}$ in GPR55-mediated and $\mathrm{G}_{i}$ in $\mathrm{CB}_{2} \mathrm{R}$-mediated signaling in neutrophils. 

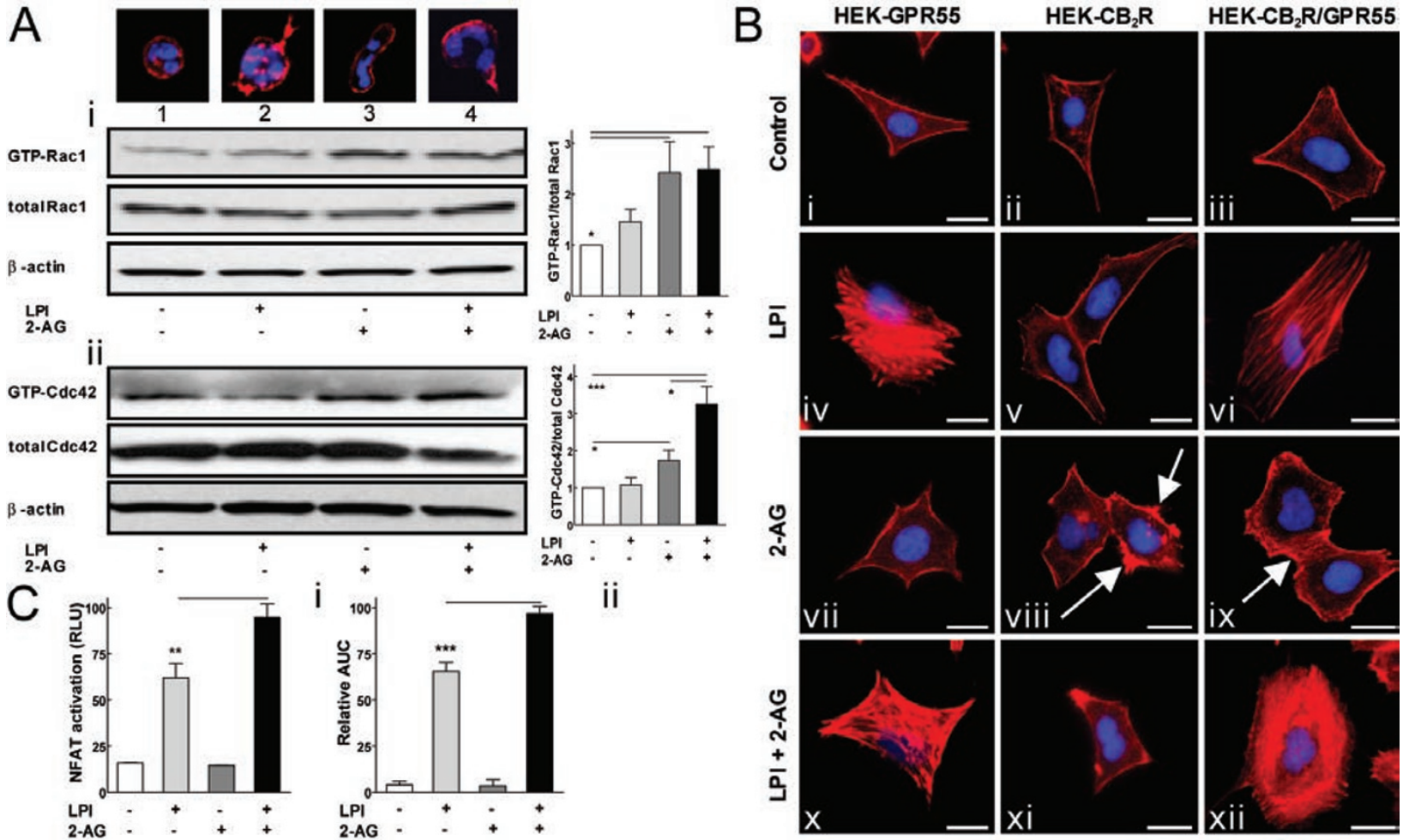

Figure 4 Cytoskeletal rearrangement of (A) neutrophils and (B) HEK293 cells requires the concomitant activation of GPR55 and $\mathrm{CB}_{2} \mathrm{R}$. (A) Neutrophils were stimulated with LPI $(1 \mu \mathrm{M}), 2-\mathrm{AG}(1 \mu \mathrm{M})$ and LPI $(1 \mu \mathrm{M})+2-\mathrm{AG}(1 \mu \mathrm{M})$ for $1 \mathrm{~min}$ at $37^{\circ} \mathrm{C}$. Active GTP-bound Rac1 and Cdc42 GTPases were extracted from the lysates with PAK domain-gluthatione agarose beads. GTP-bound and total GTPase levels were visualized by western blotting using mouse anti-Rac1 (i) and rabbit anti-Cdc42 (ii) antibodies. The $\beta$-actin served as a loading control. The ratio of GTP-bound vs total GTPase levels was assessed with ImageJ software (graphs). Representative blots from 3-4 independent experiments are shown. Data are mean \pm SEM. ( $P<$ $\left.0.05 ;{ }^{* * *} P<0.001\right)$. (B) HEK-GPR55, HEK-CB 2 R and HEK-CB 2 R/GPR55 cells were seeded on $1 \%$ PDL-coated glass coverslips. Serum-starved cells were incubated with agonists $(1 \mu \mathrm{M})$ for $10 \mathrm{~min}$ in a serum-free medium. The fixed cells were stained for F-actin by methanolic Texas-Red Phalloidin (red) and with DAPI (blue). Cells were analyzed using an OLYMPUS fluorescence microscope equipped with a Hamamatsu ORCA CCD camera (original magnification: $60 \times$ ). Scale bars: $20 \mu \mathrm{m}$. Representative images from 3-4 experiments are shown. (C) (i) HEK-CB 2 R/GPR55 cells were transfected with 200 ng of NFAT-luciferase reporter plasmid and $24 \mathrm{~h}$ later cells were stimulated with agonists $(1 \mu \mathrm{M})$ for $3 \mathrm{~h}$ in a serum-free medium. The luciferase activity was visualized using a steadylite plus kit (PerkinElmer). Luminescence (relative light units (RLU)) was measured in a TopCounter (Top Count NXT; Packard) for $5 \mathrm{~s}$. Data are mean \pm SEM from three independent experiments performed in quadruplicate $\left({ }^{* *} P<0.01\right)$ (ii) $\mathrm{HEK}-\mathrm{CB}_{2} \mathrm{R} / \mathrm{GPR} 55$ cells were challenged with ligands $(1 \mu \mathrm{M})$ and the resulting picometer shifts of reflected light wavelength against the time (s) were monitored. Transformation of optical signatures were made by using the area under the curve (AUC) values between the 1200 and $3600 \mathrm{~s}$ time points. Data were normalized and expressed as percent of maximum activation induced by LPI + 2-AG. Data are mean \pm SEM from three independent experiments performed in quadruplicate $\left({ }^{* * *} P<0.001\right)$.

Racl and Cdc42 are involved in the cytoskeletal rearrangement of neutrophils after concomitant activation of $G P R 55$ and $C B_{2} R$

The migration of leukocytes towards chemotactic agents occurs through a coordinated series of events, typically including a cytoskeletal rearrangement that relies on the function of the Rho family of small GTPases [50]. For instance, neutrophil-like dHL60 cells have been reported to elongate in response to $\mathrm{CB}_{2} \mathrm{R}$ agonists (i.e.
JWH015 and 2-AG), thereby activating Rac1 and Cdc42, while repressing RhoA [14]. However, under these conditions, dHL60 cells did not show the typical rear/front polarity of chemotaxing neutrophils.

We tested whether Rac1 and Cdc42 were differentially activated by either LPI, 2-AG or the combined application of both ligands in neutrophils. Consistent with previous reports of GPR55-mediated Rac1 activation in HEK293 cells [15], LPI $(1 \mu \mathrm{M})$ induced a rapid - albeit 
modest - activation of Rac1 in neutrophils (Figure 4Ai, lane 2). The 2-AG $(1 \mu \mathrm{M})$ induced a rapid and significant increase in activated Rac1 (Figure 4Aii, lane 3), whereby a maximum of Rac1 activity was reached within $60 \mathrm{~s}$ (Supplementary information, Figure S4). This time frame of activation is consistent with $\mathrm{CB}_{2} \mathrm{R}$-mediated Rac1 activation in dHL60 cells [14]. However, the incubation of neutrophils with both LPI and 2-AG did not result in a synergistic activation of Rac1 (Figure 4Ai, lane 4).

Activated $\mathrm{Cdc} 42$ was reported to be involved in the polarization and directional migration of neutrophils [51]. Again, $1 \mu \mathrm{M}$ LPI induced a modest activation of Cdc 42 (Figure 4Aii, lane 2), whereas $1 \mu \mathrm{M}$ 2-AG was able to promote GTP-binding to $\mathrm{Cdc} 42$ in neutrophils within 1 min (Figure 4Aii, lane 3). Interestingly, incubation of neutrophils with both agonists led to a further increase in $\mathrm{Cdc} 42$ activity compared to 2-AG alone (Figure 4Aii, lane 4).

In summary, the combined application of both the GPR55 agonist LPI and the $\mathrm{CB}_{2} \mathrm{R}$ agonist 2-AG further potentiated $\mathrm{Cdc} 42$ activity. This process may thus underlie the polarized morphology (see Figure 1Biv and 4A, top of lane 4) and the trafficking of neutrophils towards a gradient of both ligands (see Figure 1Aiii).

RhoA-dependent F-actin formation and activation of the downstream transcription factor NFAT are mediated by $G P R 55$ and enhanced in the presence of activated $C B_{2} R$

Next, we wanted to test the extent to which each of the respective receptors - i.e. GPR55 or $\mathrm{CB}_{2} \mathrm{R}$ - is involved in the formation of RhoA-dependent F-actin. Since the short life-time of purified neutrophils does not allow for manipulations such as siRNA knockdown, we took advantage of HEK293 cells stably expressing these receptors alone, or a combination thereof. We and others have previously shown that in HEK293 cells, GPR55 stimulation leads to the activation of RhoA, Rac1 and Cdc42 [15, 18].

The GPR55 agonist LPI $(1 \mu \mathrm{M}, 10 \mathrm{~min})$ induced prominent $\mathrm{F}$-actin fibers in HEK-GPR55 (Figure 4Biv) but not in $\mathrm{HEK}-\mathrm{CB}_{2} \mathrm{R}$ cells (Figure $4 \mathrm{Bv}$ ). This effect was dependent on the activity of the $\mathrm{G} \alpha_{13} /$ RhoA axis, since the transient transfection of HEK-GPR55 cells with dominant negative mutants of $\mathrm{G} \alpha_{13}$ (Supplementary information, Figure S5i) and RhoA (Supplementary information, Figure S5ii) or a 10-min pretreatment with $10 \mu \mathrm{M}$ ROCK inhibitor Y27632 (Supplementary information, Figure S5iii) prevented actin polymerization in response to $1 \mu \mathrm{M}$ LPI. Surprisingly, GPR55-mediated F-actin formation was modestly attenuated in the presence of non-activated $\mathrm{CB}_{2} \mathrm{R}$ in $\mathrm{HEK}-\mathrm{CB}_{2} \mathrm{R} / \mathrm{GPR} 55$ cells (Figure 4Bvi).

The $\mathrm{CB}_{2} \mathrm{R}$ agonist 2-AG $(1 \mu \mathrm{M})$ could not induce actin rearrangement in the HEK-GPR55 cells (Figure 4Bvii), but led to some accumulation of polymerized actin in the periphery of $\mathrm{HEK}-\mathrm{CB}_{2} \mathrm{R}$ cells (Figure 4Bviii, arrows). This effect could also be observed in HEK-CB ${ }_{2} \mathrm{R} / \mathrm{GPR} 55$ cells (Figure 4Bix, arrow). Treatment of HEK-CB ${ }_{2} \mathrm{R} /$ GPR55 cells with both LPI $(1 \mu \mathrm{M})$ and 2-AG $(1 \mu \mathrm{M})$ drastically increased the formation of filamentous actins (Figure 4Bxii) when compared with LPI (Figure 4Bvi) or 2-AG (Figure 4Bix) alone. Co-administration of LPI and 2-AG did not show a change in actin formation in HEKGPR55 (Figure 4Bx) or HEK-CB ${ }_{2} \mathrm{R}$ (Figure 4Bxi) cells compared to treatment of these cells with any of the agonists alone (compare Figure 4Bx and 4Biv and 4Bxi and 4Bviii, respectively).

We have recently shown that in HEK293 cells, the stimulation of GPR55 triggers multiple signaling pathways, eventually leading to the activation of transcription factors such as the nuclear factor of activated $\mathrm{T}$ cells (NFAT), the nuclear factor- $\mathrm{KB}$ and the cAMP responsive element binding (CREB) protein [21]. Moreover, we have reported that GPR55-mediated NFAT activation is crucially dependent on the function of RhoA [18]. Hence, we next tested whether NFAT-transcription factor activity was differentially regulated in the presence of activated GPR55 and/or $\mathrm{CB}_{2}$ receptors in our HEK-CB $\mathrm{C}_{2} \mathrm{R} / \mathrm{GPR} 55$ cell model. Concomitant activation of GPR55 and $\mathrm{CB}_{2} \mathrm{R}$ with LPI $(1 \mu \mathrm{M})$ and 2-AG $(1 \mu \mathrm{M})$ led to a significant enhancement of NFAT-activation when compared to cells stimulated with $1 \mu \mathrm{M}$ LPI only (Figure 4Ci, compare light gray and black bars). The 2-AG $(1 \mu \mathrm{M})$ did not induce NFAT activity in HEK-CB ${ }_{2}$ R/GPR55 cells (Figure $4 \mathrm{Ci}$, dark gray bar). This was expected, since $\mathrm{CB}_{2}$ receptors typically mediate their signaling events predominantly through $\mathrm{G} \alpha_{i}$-pathways, which have not been reported to induce NFAT-activity. In order to test the signaling events in the HEK- $\mathrm{CB}_{2} \mathrm{R} / \mathrm{GPR} 55$ model on a more 'global' scale, we subjected our cells to a Dynamic Mass Redistribution Assay (DMR, Epic ${ }^{\mathbb{B}}$ ). We have previously reported the suitability of this system for labelfree measurement of signaling events of both GPR55 [21] and $\mathrm{G}{ }_{i}$-coupled 7TM/GPCRs [49]. In fact, similar to our findings in the NFAT-assay, concomitant activation of GPR55 and $\mathrm{CB}_{2} \mathrm{R}$ with LPI $(1 \mu \mathrm{M})$ and 2-AG $(1 \mu \mathrm{M})$ led to a significantly higher DMR response in these cells when compared to cells stimulated with $1 \mu \mathrm{M}$ LPI only (Figure 4Cii, compare light gray and black bars). Again, 2-AG $(1 \mu \mathrm{M})$ alone did not induce any DMR in HEK$\mathrm{CB}_{2} \mathrm{R} / \mathrm{GPR} 55$ cells (Figure 4Cii, dark gray bar).

In summary, these data suggest that the LPI-induced activation of GPR55 is critical for the RhoA-dependent rearrangement of the actin cytoskeleton and downstream signaling events such as activation of the transcription 

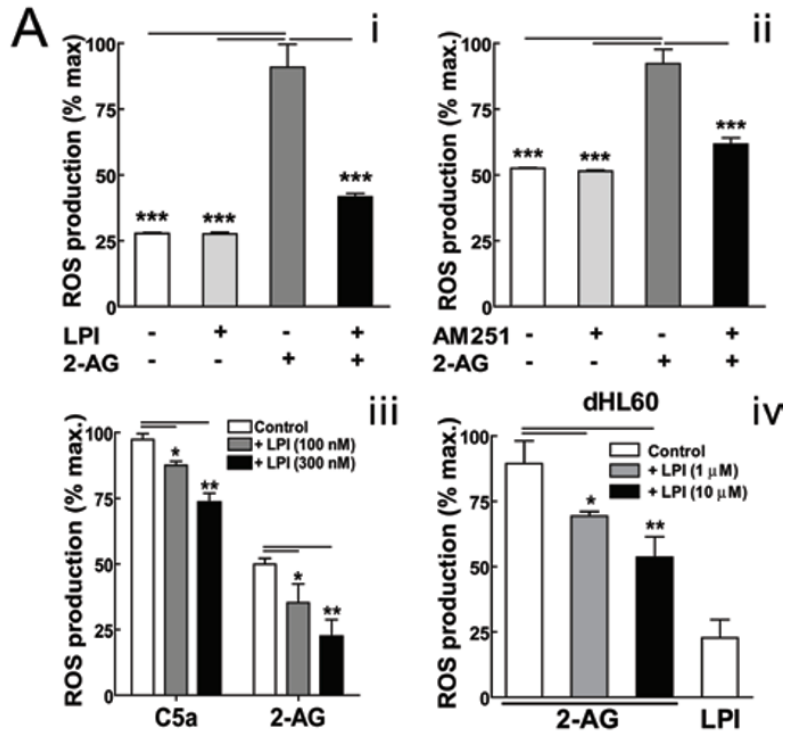

B
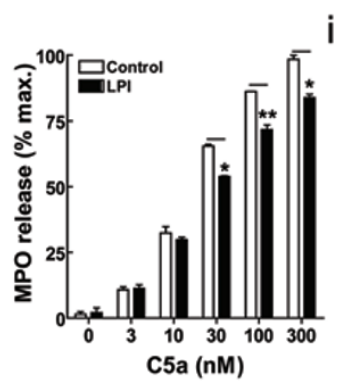

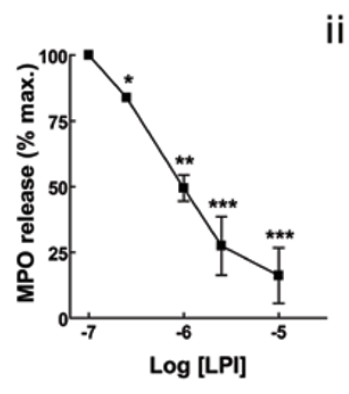

Figure 5 GPR55 activation inhibits (A) $\mathrm{CB}_{2} \mathrm{R}$-mediated respiratory burst and (B) C5a-induced degranulation in neutrophils. (A) ROS production in neutrophils was measured by flow cytometry. (i) Cells were loaded with $1 \mu \mathrm{M} 2^{\prime}, 7^{\prime}$-DCF-DA and then incubated with DMSO (0.1\%), LPI (300 nM), 2-AG $(10 \mu \mathrm{M})$ or a combination of LPI and 2-AG for $20 \mathrm{~min}$ at $37^{\circ} \mathrm{C}$. ROS production was measured as a change in fluorescence in the FL1 channel. (ii) ROS production in neutrophils was measured as in panel Ai except that AM251 (300 $\mathrm{nM}$ ) was used instead of LPI. (iii) Neutrophils were incubated with C5a (5 nM) or 2-AG $(10 \mu \mathrm{M})$ and treated with buffer (control) or LPI (100 $\mathrm{nM}$ or $300 \mathrm{nM}$ ) for 20 min. ROS production was assessed as in panel Ai. (iv) Serum-starved dHL60 cells were loaded with $5 \mu \mathrm{M}$ $2^{\prime}, 7^{\prime}$-DCF-DA for $10 \mathrm{~min}$ at $37^{\circ} \mathrm{C}$ and then incubated with 2-AG (10 $\mu \mathrm{M})$ in combination with assay buffer (control) or LPI (1 or $10 \mu \mathrm{M})$. LPI $(10 \mu \mathrm{M})$ used in combination with DMSO $(0.1 \%)$ did not induce changes in ROS levels. ROS production was recorded in a FlexStation II device (Ex. 485nm, Em. 535 nm) 20 min after ligand addition. Representatives of 3-4 independent experiments, performed in quadruplicates are shown for all subpanels. Data are mean \pm SEM $\left({ }^{*} P<0.05 ;{ }^{* *} P<0.01 ;{ }^{* * *} P<0.001\right)$. (B) (i) Neutrophils were incubated with LPI (300 nM) or assay buffer (control) for $1 \mathrm{~h}$ at 37 ${ }^{\circ} \mathrm{C}$. MPO release was induced by increasing concentrations of $\mathrm{C} 5 \mathrm{a}$ for $30 \mathrm{~min}$ and measured as the change in absorbance at $630 \mathrm{~nm}$ in a colorimetric assay. (ii) Neutrophils were incubated with increasing concentrations of $\mathrm{LPI}$ for $1 \mathrm{~h}$ at $37{ }^{\circ} \mathrm{C}$. MPO release was induced with C5a (300 nM) for 30 min and assessed as in panel $\mathrm{Bi}$. Data are mean $\pm S E M$ of three independent experiments performed in triplicates $\left({ }^{*} P<0.05 ;{ }^{* \star} P<0.01 ;{ }^{* * *} P<0.001\right)$. The MPO release induced by $300 \mathrm{nM}$ C5a was set to $100 \%$.

factor NFAT. However, these effects are enhanced in the presence of a 2-AG-activated $\mathrm{CB}_{2}$ receptor.

Activated GPR55 inhibits $C B_{2} R$ - and C5aR-mediated respiratory burst in neutrophils

A dramatic increase in ROS levels - known as the 'respiratory burst' - is a mechanism used by neutrophils to resolve infection. This process is catalyzed by the NADPH oxidase complex [52] and is regulated by the small GTPase Rac2 [38]. In neutrophils and HL60 cells, 2-AG and the complement component $5 \mathrm{a}(\mathrm{C} 5 \mathrm{a})$ have been reported to activate Rac2 via their cognate $\mathrm{G} \alpha_{i}$-coupled receptors, i.e., the $\mathrm{CB}_{2} \mathrm{R}$ and the $\mathrm{C} 5 \mathrm{aR}[14,53,54]$. Here, we tested whether the activation of GPR55 and $\mathrm{CB}_{2}$ receptors had an effect on ROS production in neutrophils.

GPR55 agonists LPI (300 nM) or AM251 (300 nM) did not induce ROS production in neutrophils per se (Figure 5Ai and 5Aii, light gray bars). In contrast, 2-AG $(10 \mu \mathrm{M})$ induced ROS production in neutrophils (Figure 5Ai and 5Aii, dark gray bars), an effect that could be inhibited with $10 \mu \mathrm{M}$ selective $\mathrm{CB}_{2} \mathrm{R}$ antagonist AM630 (Supplementary information, Figure S6). Interestingly, 2-AG-induced ROS production was significantly diminished when neutrophils were concomitantly stimulated with LPI $(300 \mathrm{nM})$ or AM251 (300 nM) (Figure 5Ai and 5Aii, black bars). This effect was dose dependent (Figure 5Aiii, $100 \mathrm{nM}-300 \mathrm{nM} \mathrm{LPI}$ ) and could also be observed in neutrophils activated with C5a (Figure 5Aiii). Similar to neutrophils, we observed that ROS formation stimulated by $2-\mathrm{AG}(10 \mu \mathrm{M})$ was significantly inhibited by coadministration of LPI (Figure 5Aiv) in dHL60 cells, although higher concentrations of LPI $(1 \mu \mathrm{M}-10 \mu \mathrm{M})$ were needed to see an effect. However, like in neutrophils, LPI alone could not induce ROS production in dHL60 cells (Figure 5Aiv).

In summary, these data show that - once activated GPR55 inhibited the $\mathrm{CB}_{2} \mathrm{R}$-mediated ROS production in both neutrophils and dHL60 cells.

\section{Activated GPR55 inhibits the C5a-induced degranula- tion of neutrophils}

In order to be able to destroy infectious agents, neutrophils store a large number of enzymes in azurophilic granules [3]. Upon activation by C5a and/or other inflammatory mediators, these granules release their enzymes - e.g., myeloperoxidase (MPO) - to the milieu [3]. Since activated GPR55 could block C5a-mediated ROS production in neutrophils (Figure 5Aiii), we next tested whether LPI could likewise modify C5a-induced MPO release. In fact, pretreatment of neutrophils with $300 \mathrm{nM}$ LPI for $1 \mathrm{~h}$ (Figure 5Bi, black bars) significantly inhibited the MPO release triggered by different concen- 
A

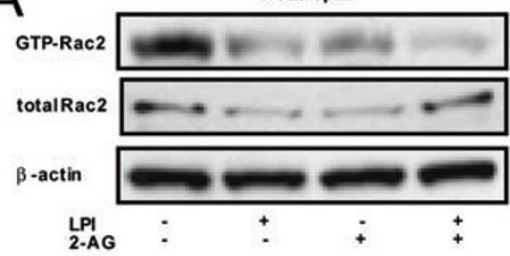

C

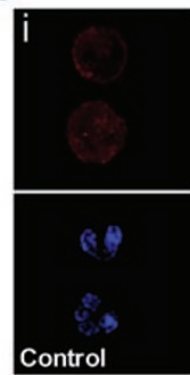

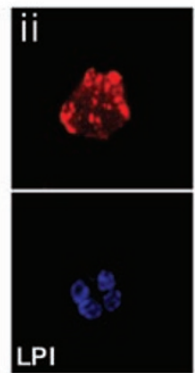
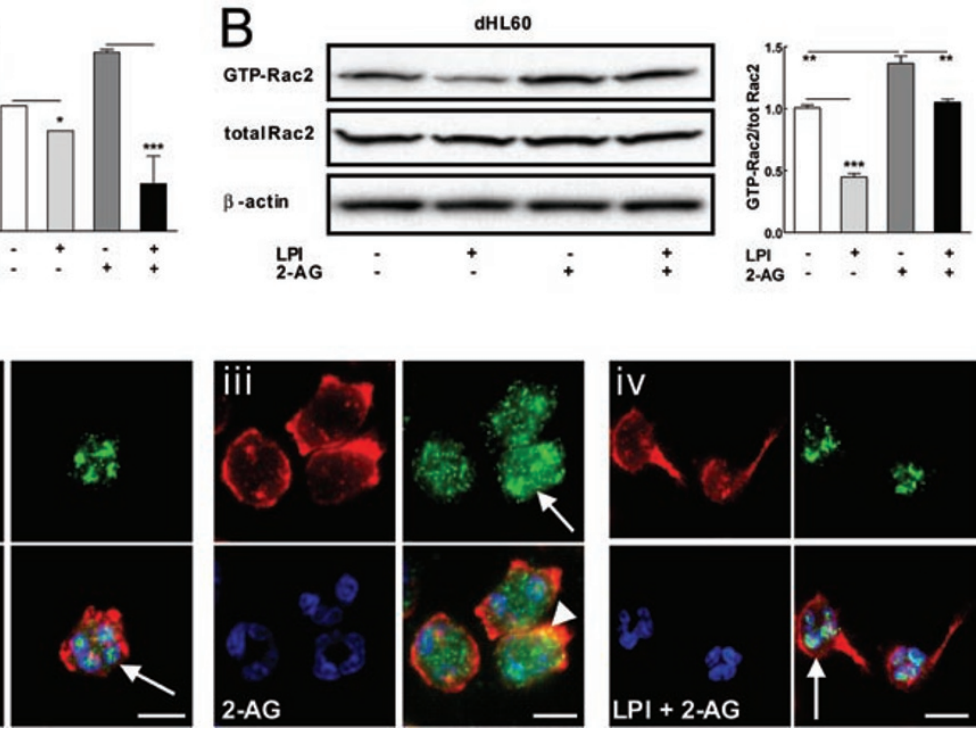

Figure 6 GPR55 activation suppresses the $\mathrm{CB}_{2} \mathrm{R}$-mediated activation and translocation of Rac2. (A) Neutrophils were stimulated with agonists $(1 \mu \mathrm{M})$ for $1 \mathrm{~min}$ at $37^{\circ} \mathrm{C}$. The active GTP-bound Rac2 was extracted from the lysates with PAK domaingluthatione agarose beads. GTP-bound and total GTPase levels were visualized by western blotting using a rabbit anti-Rac2 antibody, $\beta$-actin served as a loading control. The ratio of GTP-bound vs total GTPase levels was assessed with ImageJ software (graph). Data are mean \pm SEM of three independent experiments. ( $\left.{ }^{\star} P<0.05 ;{ }^{* *} P<0.001\right)$. (B) Serum-starved dHL60 cells were stimulated with agonists $(1 \mu \mathrm{M})$ for 1 min at $37^{\circ} \mathrm{C}$. The extraction of active GTP-bound Rac2 was performed as in panel (A). Data are mean \pm SEM of three independent experiments $\left({ }^{* *} P<0.01\right.$; $\left.{ }^{* *} P<0.001\right)$. (C) Neutrophils were seeded on fibronectin-coated glass coverslips and treated with $0.01 \%$ DMSO (control; i) or ligands for 5 min at $37^{\circ} \mathrm{C}$. Fixed cells were incubated with rabbit anti-Rac2 antibody and stained with Alexa Fluor-488 goat anti-rabbit antibody (green), Texas-Red Phalloidin (red), and DAPI (blue). Control (i) and LPI (3 $\mu \mathrm{M}$, ii) treated cells show a nuclear/perinuclear localization of Rac2 (arrows). Upon 2-AG stimulation (1 $\mu \mathrm{M}$, iii), Rac2 distributed evenly in the cytosol (arrow) and partially colocalized with actin at the plasma membrane (yellow, arrowhead). (iv) Treatment with a combination of LPI (3 $\mu \mathrm{M})$ and 2-AG (1 $\mu \mathrm{M})$ showed a nuclear localization of Rac2 in polarized neutrophils. Cells were analyzed using an OLYMPUS fluorescence microscope equipped with a Hamamatsu ORCA CCD camera (original magnification: 60x). Scale bars: $10 \mu \mathrm{m}$. Representative images from 2-3 experiments are shown.

trations of $\mathrm{C} 5 \mathrm{a}$ (Figure 5Bi, white bars). Increasing doses of LPI reduced MPO release mediated by $300 \mathrm{nM} \mathrm{C5a}$ up to a maximum of $75 \%$ (Figure $5 \mathrm{Bii}$ ). No MPO release was observed when neutrophils were incubated with LPI alone (Figure $5 \mathrm{Bi}$, black bar at 0 concentration of $\mathrm{C} 5 \mathrm{a}$ ). Thus, activated GPR55 can prevent C5a-mediated degranulation of neutrophils.

Activated GPR55 inhibits ROS production and degranulation in neutrophils via repression of Rac2 activity

It has frequently been reported that the small GTPase Rac2 regulates degranulation and the NADPH oxidase activity in neutrophils via its translocation to the plasma membrane and incorporation in the NADPH oxidase complex [53, 55]. In addition, JWH015, a synthetic $\mathrm{CB}_{2} \mathrm{R}$-specific agonist, was shown to activate Rac2 in dHL60 cells and primary neutrophils [14]. To see whether the GPR55-mediated inhibition of ROS production and degranulation is dependent on Rac2, we investigated the activation and translocation of Rac2 in response to both GPR55 and $\mathrm{CB}_{2} \mathrm{R}$ agonists in neutrophils and dHL60 cells.

Treatment of neutrophils with LPI $(1 \mu \mathrm{M})$ for $1 \mathrm{~min}$ reduced the activity of Rac2 when compared to vehicle (Figure 6A, lanes 1 and 2). In contrast, 2-AG $(1 \mu \mathrm{M})$ resulted in a significant activation of Rac2 (Figure 6A, lane 3), which reached the highest activity at $1 \mathrm{~min}$ and returned to its basal activity after 2 min (Supplementary information, Figure S7). However, concomitant stimulation of neutrophils with 2-AG $(1 \mu \mathrm{M})$ and LPI $(1 \mu \mathrm{M})$ resulted in a significant inhibition of Rac2 activity when compared to cells treated with 2-AG alone (Figure 6A, compare lanes 3 and 4). Likewise, in dHL60 cells Rac2 activity was reduced in the presence of $1 \mu \mathrm{M}$ LPI (Figure $6 \mathrm{~B}$, lane 2) and enhanced in the presence of $1 \mu \mathrm{M} 2-\mathrm{AG}$ (Figure 6B, lane 3). Again, in the presence of both ligands, the Rac2 activity was reduced when compared to dHL60 cells treated with 2-AG alone (Figure 6B, com- 
pare lanes 3 and 4).

The function of Rac2 in ROS production and degranulation is dependent on its translocation from the nuclear and/or perinuclear zones to the plasma membrane. In neutrophils, Rac2 was mainly located in or closely around the nucleus (Figure $6 \mathrm{Ci}$, arrow, Rac2 in green, DAPI/nuclear staining in blue). Treatment of neutrophils with $3 \mu \mathrm{M}$ LPI did not alter the perinuclear distribution of Rac2 (Figure 6Cii, arrow). In contrast, stimulation of neutrophils with 2-AG $(1 \mu \mathrm{M})$ induced a redistribution of Rac2 to the cytosol (Figure 6Ciii, green, arrow) and partly resulted in a colocolization with the peripheral actin (Figure 6Ciii, yellow, arrowhead). This effect, however, could be prevented by concomitant application of $3 \mu \mathrm{M}$ LPI with $1 \mu \mathrm{M}$ 2-AG, resulting in a perinuclear distribution of Rac2 in these cells (Figure 6Civ, arrow).

In summary, these data suggest that GPR55 regulates both ROS and MPO production in neutrophils via suppressing the activity of the small GTPase Rac2.

\section{Discussion}

The migration of neutrophils towards sites of inflammation is a multistep process involving various chemoattractants with overlapping gradients. The final direction of migration typically depends on (i) the sequence of chemoattractants to which neutrophils are exposed to and (ii) the crosstalk between chemoattractant receptors and their respective downstream signaling pathways [56]. Once neutrophils have been recruited to a site of infection, they form radical oxygen species and release myeloperoxidase to the milieu - both of these processes thus fulfill the bactericidal role of neutrophils $[2,55]$.

The level of endocannabinoids and LPI produced by immune cells, i.e., macrophages [7, 29], is increased during inflammatory conditions [27, 29]. Here we show that the GPR55 agonists LPI and AM251 induce a directional migration of human peripheral blood neutrophils and augment their migratory capacity towards the $\mathrm{CB}_{2} \mathrm{R}$ agonist 2-AG (Figure 1A and 1C). Further, only the concomitant treatment with gradients of both GPR55 and $\mathrm{CB}_{2} \mathrm{R}$ agonists leads to a remodeling of the cytoskeleton and the formation of a rear-front polarity in neutrophils (Figure 1B). These latter processes are typically mediated by members of the small GTPase family, i.e., RhoA, Rac1 and Cdc42. While RhoA governs actin polymerization and the formation of a contracting tail in migrating neutrophils, Rac1 is responsible for the formation of a leading edge ('head') of polarized neutrophils and $\mathrm{Cdc} 42$ determines the direction of migration [25, 51, 57-59]. It was previously shown that GPR55 agonists lead to the activation of RhoA, Rac1 and Cdc42 in HEK-GPR55 cells $[15,18]$. Here, we did not observe a significant activation of Rac1 and Cdc42 in neutrophils upon treatment with LPI alone (Figure 4A, lanes 2), but, interestingly, $\mathrm{CB}_{2} \mathrm{R}$-mediated activation of $\mathrm{Cdc} 42$ was significantly enhanced by LPI (Figure 4Aii, lane 4). Likewise, a concerted action of both $\mathrm{CB}_{2} \mathrm{R}$ and GPR55 agonists induced a potent RhoA-dependent rearrangement of the actin cytoskeleton (Figure 4B) and a downstream activation of the transcription factor NFAT and changes in DMRsignatures (Figure 4C). Considering the synergistic effects of GPR55- and $\mathrm{CB}_{2} \mathrm{R}$-mediated $\mathrm{Cdc} 42$ activation in neutrophils, as well as the increased NFAT activation and DMR signals in HEK-CB $\mathrm{B}_{2} / \mathrm{GPR} 55$ cells, we believe that these receptors intersect with each other's signaling pathways. This crosstalk between GPR55 and $\mathrm{CB}_{2} \mathrm{R}$, and the consequent morphological changes in neutrophils, are in line with the higher migratory efficiency of these cells towards a gradient of both receptor agonists, LPI and 2-AG (Figure 1).

LPI/GPR55-provoked effects were mediated via a $\mathrm{Ga}_{13} /$ RhoA signaling pathway in neutrophils. C3 toxin blocked the cytoskeletal rearrangement (Figure 3B) and migration (Figure 3A) of neutrophils induced by LPI when LPI was used alone or in combination with 2-AG. In addition, the blockade of F-actin formation in HEKGPR55 cells following expression of dominant negative mutants of $\mathrm{G \alpha}_{13}$ and RhoA or pretreatment with the ROCK inhibitor Y27632 revealed a pivotal role of the $\mathrm{G} \alpha_{13} / \mathrm{RhoA} / \mathrm{ROCK}$ signaling cascade in GPR55-mediated functions (Supplementary information, Figure S5). This is in line with other studies performed in HEK293 cells, where a dominant negative mutant of $\mathrm{G} \alpha_{13}$ inhibited the $\mathrm{Ca}^{2+}$ release from intracellular stores [18, 19]. Moreover, a recent study showed the inhibitory effect of $\mathrm{C} 3$ toxin and the ROCK inhibitor Y27632 on GPR55-mediated activation of the p38 MAP kinase and one of its downstream targets, the transcription factor ATF-2 in HEK293 cells [60].

Coupling of the $\mathrm{CB}_{2} \mathrm{R}$ to $\mathrm{G}_{i / o}$ subunits has been welldescribed in a variety of cell models $[12,61,62]$. Here, we confirmed the involvement of $\mathrm{G}_{i}$ in the $\mathrm{CB}_{2} \mathrm{R}$-mediated migration and cytoskeleton rearrangement by preincubating neutrophils with pertussis toxin (Figure 3A and $3 \mathrm{~B})$.

We further show that the activation of GPR55 significantly inhibited 2-AG- or C5a-induced (i) ROS production (Figure 5A) and (ii) MPO release (Figure 5B) in neutrophils and neutrophil-like differentiated HL60 cells. It was previously suggested that Rac2 was required for azurophilic granule exocytosis and NADPH oxidase activity $[38,63]$ and that neutrophils from $\mathrm{Rac}_{2}{ }^{-/-}$mice were deficient in ROS production and MPO release [64]. 
Considering the reported activation of Rac 2 by $\mathrm{CB}_{2} \mathrm{R}$ agonists [14], we tested whether Rac2 activity was regulated by GPR55. In fact, activated GPR55 reduces the Rac2 activity in both 2-AG-stimulated neutrophils (Figure 6A) and dHL60 cells (Figure 6B). Moreover, GPR55 activation prevents $2-\mathrm{AG}$-mediated Rac2 translocation from the perinuclear zones to the cytosol (Figure 6C).

Rho family small GTPases control a wide variety of cellular functions, including cell permeability, migration and ROS production in physiological and pathophysiological conditions. These cellular processes are finetuned via a spatiotemporal crosstalk between Rho family GTPases. For instance, it was shown that Ras [65] or Cdc42 [66] activates Rac, which in turn activates RhoA, and this cascade enhances F-actin formation and membrane ruffling. However, there are instances where Rac inhibits RhoA activation [67, 68].

Although the exact mechanism of Rac2 inhibition by GPR55 still remains elusive, it is tempting to speculate that $\mathrm{Cdc} 42$ is involved in this process. For instance, it was reported that the inactivation of $\mathrm{Cdc} 42$ - via a $\mathrm{Cdc} 42$ binding domain of Wiskott-Aldrich syndrome protein - causes a remarkable increase in ROS production [39, 64]. Moreover, $\mathrm{Cdc} 42$ competes with Rac 2 for binding to the flavocytochrome $b_{558}$, a major component of NADPH oxidase [39]. Another study showed that active Cdc42 forms a dimer with active GTP-bound Rac2, thereby enhancing the GTPase activity of Rac2 and leading to a higher rate of GTP hydrolysis by Rac2 [69]. Thus, enhanced activation of $\mathrm{Cdc} 42$ in the presence of both LPI and 2-AG (Figure 4Aii) may be responsible for (i) the inhibition of Rac2 activation and its translocation and (ii) the subsequent inhibition of ROS production in polarized neutrophils.

The impact of 2-AG and other $\mathrm{CB}_{2} \mathrm{R}$ agonists on migration of hematopoietic cells has been controversial. While one study showed an inhibitory effect of 2-AG on fMLP-induced migration [14], another study suggested that 2-AG does not modulate the fMLP-induced migration of neutrophils and is thus not chemotactic by itself [31]. In contrast, 2-AG was shown to induce migration of the myeloid cell line NFS [33], mouse neopallia micro-

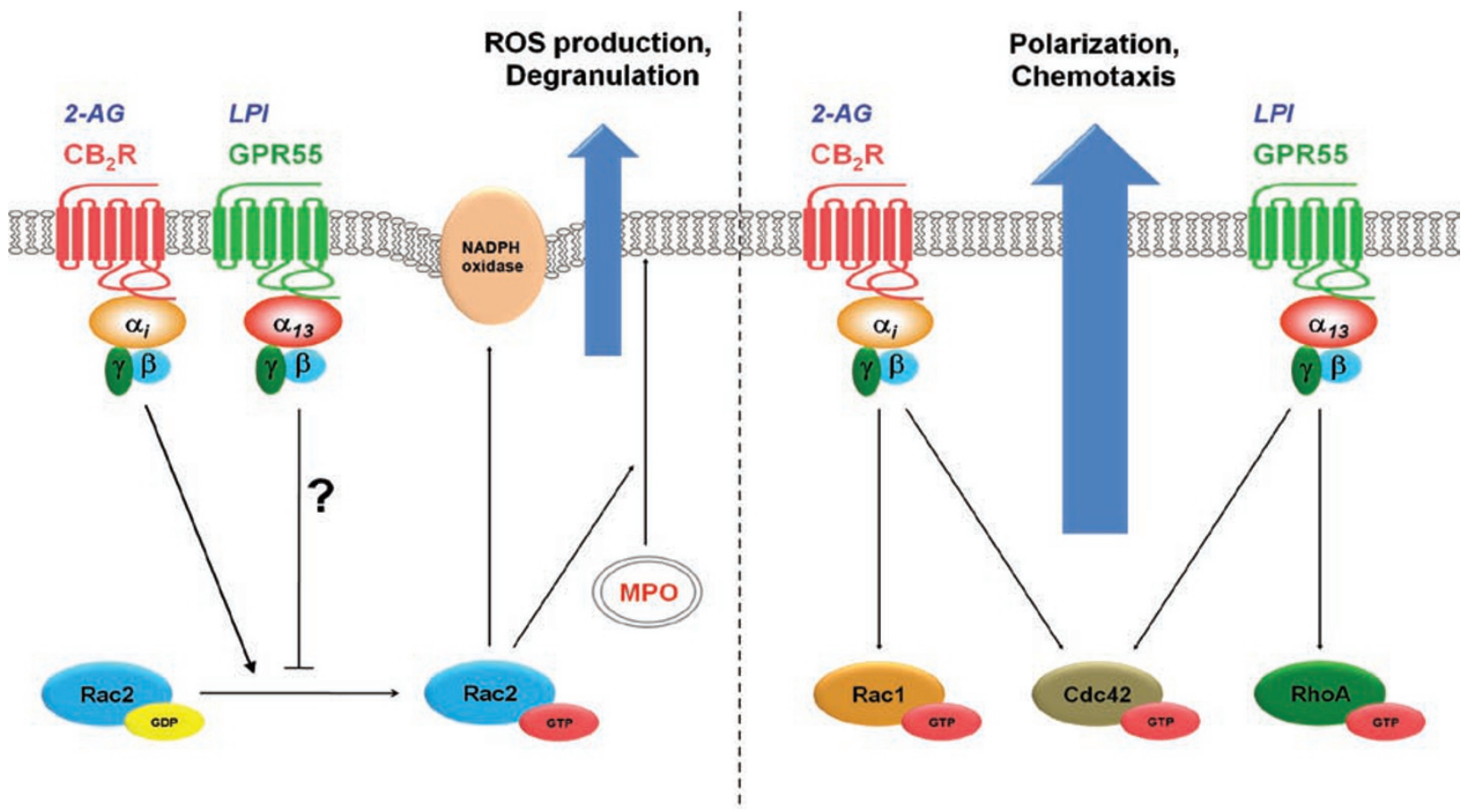

Figure 7 Crosstalk between GPR55 and $\mathrm{CB}_{2} \mathrm{R}$ and its consequent biological responses in human blood neutrophils. (right panel) Stimulation of $\mathrm{CB}_{2} \mathrm{R}$ and GPR55 by 2-AG and LPI, respectively, leads to a coordinated activation of RhoA, Rac1 and Cdc42 small GTPases. This leads to a distinct remodeling of cytoskeleton (polarization) compared to sole activation of each receptor and facilitates neutrophils migration towards the gradient of agonists. (left panel) The bacterial killing mechanisms, which are provoked by $\mathrm{C} 5 \mathrm{a}$ or 2-AG, are mediated via the activation of Rac2 small GTPases. Active Rac2 will translocate and incorporate to the NADPH oxidase core complex in the phagocytic cup and catalyzes the formation of reactive oxygen species (ROS). On the other hand, it facilitates degranulation of neutrophils via translocation of azurophilic granules, containing myeloperoxidase (MPO). Stimulation of GPR55 by LPI, via a yet unknown mechanism, inhibits activation of Rac2, thereby limiting the ROS production and degranulation. 
glial cells [34] and EoL-1 human eosinophilic leukemia cells [35]. In the current study we show that 2-AG induces migration of neutrophils, but this effect is enhanced in the presence of activated GPR55.

In conclusion, our data suggest that a crosstalk between GPR55 and $\mathrm{CB}_{2} \mathrm{R}$ exists at the level of small GTPases, which in turn enables neutrophils to efficiently migrate towards sites of inflammation while preventing exaggerated tissue injury mediated by MPO release and ROS production (Figure 7).

\section{Materials and Methods}

\section{Reagents and plasmids}

Phosphate buffered saline (PBS, with or without $\mathrm{Ca}^{2+}$ and $\mathrm{Mg}^{2+}$ ) was from Invitrogen. Fatty acid-free BSA (BSAfaf), gluthatione agarose beads, fibronectin, 2', $7^{\prime}$-dichlorofluorescein diacetate $\left(2^{\prime}, 7^{\prime}\right.$-DCF-DA), poly-D-lysine (PDL), pertussis toxin and L- $\alpha$-LPI mixture $(58 \%$ C16, 42\% C18) were from Sigma. AM251 ( $N$-(piperidin-1-yl)-5-(4-iodophenyl)-1-(2,4-dichlorophenyl)-4methyl-1H-pyrazole-3 carboxam-ide), AM630 (6-Iodo-2-methyl1-[2-(4-morpholinyl)ethyl]-1H-indol-3-yl](4-methoxyphenyl) methanone), 2-AG ((5Z,8Z,11Z,14Z)-5,8,11,14-eicosatetraenoic acid, 2-hydroxy-1-(hydroxymethyl)ethyl ester) and (-)-cannabidiol (CBD) (2-[(1R,6R)-3-methyl-6-(1-methylethenyl)-2-cyclohexen1-yl]-5-pentyl-1,3-benzenediol) were purchased from Tocris Bioscience. The rabbit polyclonal anti-Rac2 antibody was obtained from Santa Cruz and the mouse monoclonal anti-Racl antibody was purchased from BD Bioscience. Rabbit monoclonal antiCdc42 antibody was from Cell Signaling (Austria). The rabbit anti-human $\mathrm{CB}_{2} \mathrm{R}$ antibody (Affinity BioReagents) was a gift from Cristina Sanchez (Complutense University, Madrid, Spain). Mouse anti-human $\beta$-actin antibody was obtained from Sigma. Alexa Fluor-594 goat anti-rat and Alexa Fluor-488 goat anti-abbit antibodies were obtained from Molecular Probes. HRP-conjugated goat antirabbit, HRP-conjugated goat anti-mouse and HRP-conjugated goat anti-rat antibodies were from Jackson ImmunoResearch. Antihuman CD11b-FITC, CD16-FITC and CD16-PE antibodies were obtained from BD Bioscience. Phenylmethylsulfonyl fluoride (PMSF), aprotinin, leupeptin and nonidet P40 were purchased from Roche Applied Science. Cell-permeable C3 toxin was obtained from Cytoskeleton and the ROCK inhibitor Y27632 was purchased from Calbiochem.

The FLAG- $\mathrm{CB}_{2} \mathrm{R}$ plasmid was generated by fusing the signaling peptide sequence/FLAG epitope (MKTIIALSYIFCLVFA/ DYKDDDDA) N-terminally to the human $\mathrm{CB}_{2} \mathrm{R}$ in the pcDNA3.1 $(+$, Zeo) vector. The pGEX-T-PAK N plasmid was kindly provided by Silvio Gutkind from the National Institutes of Health (Bethesda, USA). The dominant negative mutants of RhoA (pcDNA3-3xHARhoA-T19N) and of $\mathrm{G \alpha}_{13}$ (pcDNA3-Ga $\left.\alpha_{13}-\mathrm{Q} 226 \mathrm{~L} / \mathrm{D} 294 \mathrm{~N}\right)$ were kindly provided by Andrew Irving, University of Dundee (Scotland).

\section{Cells}

Human blood neutrophil isolation Peripheral blood from healthy volunteers was collected according to a protocol approved by the Ethics Committee of the Medical University of Graz. All volun- teers provided informed consent. In brief, platelet-rich plasma was removed by centrifugation of citrated whole blood, after which erythrocytes and platelets were removed by dextran sedimentation. Polymorphonuclear leukocytes, containing eosinophils and neutrophils, and peripheral blood mononuclear cells, including monocytes, basophils, and lymphocytes, were separated by Histopaque (Sigma) gradients centrifugation. Neutrophils were isolated from polymorphonuclear leukocytes by a non-column negative selection system using a human neutrophil enrichment kit (STEMCELL Technologies) after two times enrichment. The purity was $>99.8 \%$ as characterized by CD16-FITC in a FACSCalibur flow cytometer (Becton Dickinson, CA, USA). The viability of cells was more than $96 \%$, as assessed by using a NucleoCounter YC-100 (ChemoMetec). Cells were washed twice in PBG buffer (PBS without $\mathrm{Ca}^{2+}$ and $\mathrm{Mg}^{2+}$, HEPES $10 \mathrm{mM}$, glucose $10 \mathrm{mM}$, BSAfaf $0.1 \%, \mathrm{pH}$ 7.4) before all assays. All steps were performed at room temperature. All functional assays of neutrophils were performed in the assay buffer (PBS with $\mathrm{Ca}^{2+}$ and $\mathrm{Mg}^{2+}$, HEPES $10 \mathrm{mM}$, glucose 10 $\mathrm{mM}$, BSAfaf $0.1 \%$, $\mathrm{pH} 7.4$ ).

HL60 cells The promyelocytic HL60 cells were grown in RPMI1640 (PAA) supplemented with L-glutamine $(2 \mathrm{mM})$ and $10 \%$ fetal bovine serum (FBS) at $37{ }^{\circ} \mathrm{C}$ with $5 \% \mathrm{CO}_{2}$. Cell differentiation was triggered by addition of DMSO (1.75\%) for 4 days (dHL60 cells) [70]. To check the differentiation from undifferentiated (uHL60) to differentiated neutrophil-like (dHL60) cells, CD11b surface expression was checked by flow cytometry with a CD11bFITC antibody (1:30). In addition, DAPI staining visualized the multi-lobular nuclei of HL60 cells after differentiation. Previous to all functional assays HL60 cells were kept on low serum $(2.5 \%$ FBS) overnight in RPMI. All functional assays of HL60 cells were performed in the assay buffer (PBS with $\mathrm{Ca}^{2+}$ and $\mathrm{Mg}^{2+}$, HEPES $10 \mathrm{mM}$, glucose $10 \mathrm{mM}$, BSAfaf $0.1 \%, \mathrm{pH} 7.4$ ).

HEK293 cell lines AD-HEK293 (HEK293) and AD-HEK-GPR55 (HEK-GPR55) cells stably expressing a 3xHA-tagged human GPR55 were previously described $[18,21]$. To generate clonal stable AD-HEK293 cell line expressing $\mathrm{CB}_{2} \mathrm{R}$ or cells co-expressing GPR55 and $\mathrm{CB}_{2} \mathrm{R}, \mathrm{AD}-\mathrm{HEK} 293$ or AD-HEK-GPR55 cells, respectively, were tranfected with SS-FLAG- $\mathrm{CB}_{2} \mathrm{R}$ and single colonies were chosen and propagated in appropriate selection media $(0.2$ $\mathrm{mg} / \mathrm{ml}$ Zeocine) in DMEM (Invitrogen) supplemented with $10 \%$ FBS at $37{ }^{\circ} \mathrm{C}$ and $5 \% \mathrm{CO}_{2}$. For all functional assays, HEK293 cells were serum-starved prior to the assay in OptiMEM (Invitrogen) overnight.

\section{$R N A$ extraction, $R T-P C R$ and quantitative real time PCR}

Total RNA was extracted from cells using an RNeasy Mini Kit (QIAGEN). For RT-PCR, total RNA was reverse transcribed by using the Omniscript RT kit (QIAGEN) with OligodT primers according to manufacturer protocols. PCR was performed using taq polymerase (Fermentas) and primers for the human GPR55, $\mathrm{CB}_{1} \mathrm{R}$, $\mathrm{CB}_{2} \mathrm{R}$ and GAPDH (GPR55 (forward: 5'-CCTCCCATTCAAGATGGTCC-3'; reverse: 5'- GACGCTTCCGTACATGCTGA-3'), $\mathrm{CB}_{1} \mathrm{R}$ (forward: 5'-CCTTCCTACCACTTCATCGGC-3'; reverse: 5'-CGTTGCGGCTATCTTTGCG-3'), CB 2 R (forward: 5'- GACCGCCATTGACCGATACC-3'; reverse: 5'-GGACCCACATGATGCCCAG-3') and GAPDH (forward: 5'-ATGGGGAAGGTGAAGGTCG-3'; reverse: 5'-GGGGTCATTGATG-GCAA- 
CAATA-3')). For real time PCR, $1 \mu \mathrm{g}$ of total RNA was reverse transcribed by using a High Capacity cDNA Reverse Transcription Kit (Applied Biosystems). PCR was performed in a Mastercycler (Eppendorf) by using a Fast SYBR Green PCR Master Mix (Applied Biosystems). Standard curves for GPR55, $\mathrm{CB}_{1} \mathrm{R}$ and $\mathrm{CB}_{2} \mathrm{R}$ were calculated by using the pcDNA3.1 plasmids encoding the respective genes; $\mathrm{Ct}$ values were plotted versus gene copy number and absolute mRNA copy number was calculated accordingly. Data analysis of the relative real time PCR was based on the $2^{-\Delta \Lambda \mathrm{Ct}}$ method [71].

\section{Generation of the GPR55 antibody}

Rat polyclonal antibodies were raised as a custom genetic immunization (Genovac, Freiburg, Germany). In order to evoke an immune response, a GENOVAC immunization vector encoding the C-terminal portion (aa 301-327) of mouse GPR55 was applied intradermally to the skin of Wistar rats using a Biorad GeneGun. Sera were tested at 11 weeks by flow cytometry using HEK293derived BOSC23 cells transiently transfected with a GENOVAC test vector encoding the same protein fragment, and goat antirat IgG-RPE (Southern Biotech) as secondary. Final bleeds were taken 91 days after immunization.

\section{Immunoflourescence}

Expression of GPR55 Expression levels of GPR55 on neutrophils and HL60 cells were determined using a specific antibody developed against the C-terminus of the mouse GPR55 (rat anti-GPR55 antibody). Cells were spun on glass coverslips using a cytospin 3 centrifuge (Shandon) and fixed in 3.7\% paraformaldehyde for 20 min at RT. Subsequently, cells were permeabilized with $0.3 \%$ Triton $\mathrm{X}-100$ in PBS including 1\% BSA for $20 \mathrm{~min}$ and were incubated with the rat anti-GPR55 antibody $(1: 250)$ overnight at $4{ }^{\circ} \mathrm{C}$. Receptors were visualized with an Alexa Fluor-594 goat anti-rat antibody (1:250) for $30 \mathrm{~min}$ at RT before mounting the cells on glass slides with Vectashield mounting medium including DAPI (Vector Laboratories Inc). HEK293 and HEK-GPR55 cells were subjected to the same procedures as above, but seeded on $1 \%$ PDL coated glass coverslips and serum starved overnight prior to the experiment.

Phalloidin staining Neutrophils were seeded on glass coverslips coated with $25 \mu \mathrm{g} / \mathrm{ml}$ fibronectin for $30 \mathrm{~min}$ in the assay buffer at $37{ }^{\circ} \mathrm{C}$. Cells were treated with ligands for $5 \mathrm{~min}$ at $37^{\circ} \mathrm{C}$ and fixed in $3.7 \%$ paraformaldehyde for $10 \mathrm{~min}$ at RT. Then, cells were permeabilized with $0.5 \%$ Triton X-100 in PBS and blocked with $1 \%$ BSA in PBS for 25 min. Subsequently, cells were stained with $0.8 \mathrm{U}$ of methanolic Texas-Red Phalloidin (Invitrogen) for 20 min. Following staining, cells were mounted on glass slides with Vectashield-DAPI mounting medium. In assays requiring the inhibition of the $\mathrm{G} \alpha$-subunits $\mathrm{G} \alpha_{12 / 13}$ or $\mathrm{G} \alpha_{i}$, neutrophils were preincubated with either $\mathrm{C} 3$ toxin $(3 \mu \mathrm{g} / \mathrm{ml})$ or pertussis toxin (PTX, 3 $\mu \mathrm{g} / \mathrm{ml}$ ), respectively, for $2 \mathrm{~h}$ at $37{ }^{\circ} \mathrm{C}$ in PBG buffer. HEK293 cells were serum starved for $16 \mathrm{~h}$ prior to the experiment and stimulated with $1 \mu \mathrm{M}$ LPI for $10 \mathrm{~min}$ at $37{ }^{\circ} \mathrm{C}$. After fixation in $3.7 \%$ paraformaldehyde, all other steps were performed as described for the neutrophils, except that cells were permeablized with $0.1 \%$ Triton $\mathrm{X}-100$ for $5 \mathrm{~min}$ at RT.

Co-staining of Rac2 with actin Neutrophils were resuspended in assay buffer and seeded on glass coverslips coated with $25 \mu \mathrm{g} / \mathrm{ml}$ fibronectin. Cells were stimulated with ligands for $5 \mathrm{~min}$ at $37{ }^{\circ} \mathrm{C}$ and fixed in 3.7\% paraformaldehyde. After blocking in PBS (containing $0.5 \%$ Triton X-100 and 3\% non-fat dry milk), cells were incubated with the rabbit polyclonal anti-Rac2 (1:200) antibody for $1 \mathrm{~h}$, followed by staining with Alexa Fluor-488 goat anti-rabbit antibody $(1: 200 ; 1 \mathrm{~h})$. Subsequently, cells were incubated with 0.8 $\mathrm{U}$ of methanolic Texas-Red Phalloidin (Invitrogen) for $20 \mathrm{~min}$ and mounted with Vectashield-DAPI onto glass slides.

\section{MicroBoyden chamber chemotaxis assay}

Neutrophil migration was evaluated using a 48-well microBoyden chamber (NeuroProbe) with a $5-\mu \mathrm{m}$ pore-size polycarbonate filter. Ligands $(30 \mu \mathrm{l})$ were added to the wells of the bottom chamber and neutrophils resuspended in the assay buffer $(50 \mu$; $2 \times 10^{6}$ cells $/ \mathrm{ml}$ ) were added to the upper chamber and incubation was performed for $1 \mathrm{~h}$ at $37^{\circ} \mathrm{C}$. The migrated cells in the bottom wells were counted by flow cytometry. The chemotactic index was defined as the number of cells migrated towards the ligand divided by the number of cells migrated towards $0.01 \%$ DMSO as vehicle. In some experiments neutrophils were pre-incubated with DMSO $(0.05 \%)$, CBD $(5 \mu \mathrm{M})$ or AM630 $(5 \mu \mathrm{M})$ for $10 \mathrm{~min}$ at $37^{\circ} \mathrm{C}$. In assays requiring the inhibition of the $\mathrm{G} \alpha$-subunits $\mathrm{G} \alpha_{12 / 13}$ or $\mathrm{G \alpha}_{i}$, neutrophils were pre-incubated with either $\mathrm{C} 3$ toxin $(3 \mu \mathrm{g} / \mathrm{ml})$ or pertussis toxin (PTX, $3 \mu \mathrm{g} / \mathrm{ml}$ ), respectively, for $2 \mathrm{~h}$ at $37{ }^{\circ} \mathrm{C}$ in PBG buffer.

\section{Respiratory burst}

The respiratory burst of neutrophils was evaluated as previously described [72]. In brief, neutrophils $\left(2 \times 10^{7}\right.$ cell $\left./ \mathrm{ml}\right)$ suspended in PBG buffer were stained with an anti-human CD16-PE antibody for $10 \mathrm{~min}$ at RT. Cells were then resuspended in the assay buffer and loaded with $1 \mu \mathrm{M}$ of the non-fluorescent compound, $2^{\prime}, 7^{\prime}$-DCF-DA for $5 \mathrm{~min}$ at $37^{\circ} \mathrm{C}$. Ligands prepared in the assay buffer were mixed with equal volume of cells and kept at $37^{\circ} \mathrm{C}$ for $20 \mathrm{~min}$ and then fixed with $100 \mu \mathrm{l}$ of ice-cold fixative (Cell Fix, buffered formaldehyde from Becton-Dickinson). Respiratory burst was immediately analyzed by flow cytometry and measured as an increase in fluorescence in the FL- 1 channel. The ROS production in dHL60 cells was assessed in a FlexStation II device (Molecular Devices, USA). The dHL60 cells were seeded on 1\% PDL-coated black bottom-clear plates at a density of $2 \times 10^{5}$ cells/well. Cells were loaded with $5 \mu \mathrm{M}$ of $2^{\prime}, 7^{\prime}$-DCF-DA in the assay buffer for $10 \mathrm{~min}$ at $37^{\circ} \mathrm{C}$. ROS production was measured as an increase in fluorescence immediately after ligand application and recorded for $20 \mathrm{~min}$, using excitation and emission filters of 485 and $535 \mathrm{~nm}$, respectively.

\section{Degranulation assay}

Release of myeloperoxidase (MPO) was evaluated as previously described [73] with minor modifications. Briefly, cells were incubated with agonists for $1 \mathrm{~h}$ at $37{ }^{\circ} \mathrm{C}$ at a density of $4 \times 10^{6}$ cell $/ \mathrm{ml}$ in the assay buffer. Then cells were exposed to $5 \mu \mathrm{g} / \mathrm{ml}$ cytochalasin $\mathrm{B}$ followed by incubation with $\mathrm{C} 5 \mathrm{a}$ at concentrations indicated for $30 \mathrm{~min}$ at $37^{\circ} \mathrm{C}$ in 96 -well microplates. Tetramethylbenzidine $(70 \mu \mathrm{l}$ at $2.8 \mathrm{mM})$ was added to the plate followed by $60 \mu \mathrm{l}$ of $\mathrm{H}_{2} \mathrm{O}_{2}(1 \mathrm{mM})$. The peroxidase enzymatic reaction was stopped after 1 min by addition of $50 \mu 1$ of acetic acid (4 M) including $10 \mathrm{mM}$ sodium azide. MPO levels were determined in a microplate reader (Bio-Rad) at $630 \mathrm{~nm}$. 
Glutathione S-transferase (GST) pull down assays for small GTPases

The GST-fusion protein pGEX-T-PAK N containing the p21activated-kinase domain (PAK) for Rac1, Rac2 and Cdc42 was expressed in XL BLUE Top 10 E. coli and bound onto gluthatione agarose beads [74]. Neutrophils and HL60 cells were prewarmed to $37^{\circ} \mathrm{C}$ for $10 \mathrm{~min}$ in the assay buffer. Cells were stimulated with $1 \mu \mathrm{M}$ ligand for the time points indicated and immediately lysed on ice for $10 \mathrm{~min}$ in lysis buffer $(50 \mathrm{mM}$ Tris- $\mathrm{HCl}, 200 \mathrm{mM} \mathrm{NaCl}$, $10 \mathrm{mM} \mathrm{MgCl}, 1 \mathrm{mM}$ DTT, $1 \mathrm{mM}$ PMSF, $10 \mu \mathrm{g} / \mathrm{ml}$ aprotinin, $10 \mu \mathrm{g} / \mathrm{ml}$ leupeptin, 5\% glycerol and 1\% nonidet P-40). Cleared lysates were incubated with $30 \mu \mathrm{g}$ of pre-chilled PAK-gluthatione agarose beads for $30 \mathrm{~min}$ at $4{ }^{\circ} \mathrm{C}$, washed extensively and eluted in SDS sample buffer at $90{ }^{\circ} \mathrm{C}$ for $5 \mathrm{~min}$. Samples were resolved on $16 \%$ Tris-glycine precast gels and electroblotted onto polyvinylidene fluoride membranes (Millipore). Blots were blocked in TBST buffer $\left(1 \mathrm{mM} \mathrm{CaCl}_{2}, 136 \mathrm{mM} \mathrm{NaCl}, 2.5 \mathrm{mM} \mathrm{KCl}, 25 \mathrm{mM}\right.$ Tris- $\mathrm{HCl}, 0.1 \%(\mathrm{v} / \mathrm{v})$ Tween 20$)$, containing $5 \%$ non-fat dry milk for $1 \mathrm{~h}$ and then incubated with anti-Rac1 (1:4 000), anti-Rac2 (1:1 000) or anti-Cdc42 (1:1 000) antibodies at $4{ }^{\circ} \mathrm{C}$ overnight. After washing, blots were incubated for $2 \mathrm{~h}$ with either HRP-conjugated goat anti-rabbit (1:4 000) or HRP-conjugated goat anti-mouse (1:4 000) antibodies and proteins were visualized using ECL Western Blotting Substrate (Pierce Thermo Fisher Scientific).

\section{Immunoblotting}

Confluent 10 -cm dishes of HEK293 cells, $1 \times 10^{7}$ HL-60 cells or neutrophils were washed twice in ice-cold PBS and lysed on ice in $800 \mu \mathrm{l}$ of IPB lysis buffer containing $10 \mathrm{mM}$ Tris- $\mathrm{HCl}$ $\mathrm{pH}$ 7.4, $150 \mathrm{mM} \mathrm{NaCl}, 25 \mathrm{mM} \mathrm{KCl}, 1 \mathrm{mM} \mathrm{CaCl}_{2}, 0.1 \%$ Triton $\mathrm{X}-100$ and protease inhibitors (Roche Applied Science). After centrifugation, supernatants were collected and resolved by SDS/ PAGE using 4\%-20\% Tris-glycine precast gels (Invitrogen). After transfer to polyvinylidene difluoride membrane (Millipore, USA), blots were blocked in TBST buffer $\left(1 \mathrm{mM} \mathrm{CaCl}_{2}, 136 \mathrm{mM} \mathrm{NaCl}\right.$, $2.5 \mathrm{mM} \mathrm{KCl}, 25 \mathrm{mM}$ Tris-HCl, 0.1\% (v/v) Tween 20) containing $1 \%$ BSA (for GPR55) or 5\% BSA (for $\mathrm{CB}_{2} \mathrm{R}$ ) and incubated with the rat anti-GPR55 $(1: 1000)$ or rabbit anti-CB $\mathrm{CB}_{2} \mathrm{R}(1: 1000)$ antibodies overnight at $4{ }^{\circ} \mathrm{C}$. Blots were then incubated with HRPconjugated goat anti-rat (1:4 000; Jackson ImmunoResearch) or HRP-conjugated goat anti-rabbit (1:5 000; Jackson ImmunoResearch) antibodies for $2 \mathrm{~h}$ at RT. Blots were re-probed for $\beta$-actin with a mouse anti-human $\beta$-actin antibody $(1: 4000)$ followed by HRP-conjugated goat anti-mouse antibody (1:4 000; Jackson ImmunoResearch). Receptors and $\beta$-actin were visualized by Pierce ECL Western Blotting Substrate (Thermo Fisher Scientific).

\section{Reporter gene assays}

Transcription factor luciferase assays were performed essentially as described previously $[18,21]$. In brief, $\mathrm{HEK}-\mathrm{CB}_{2} \mathrm{R} /$ GPR55 cells (20 000 cells/well) were seeded on 1\% PDL coated 96-well plates and transiently transfected with the cis-reporter plasmid (PathDetect; Stratagene) for NFAT (200 ng/well) using Lipofectamine 2000 . At $24 \mathrm{~h}$ post-transfection, cells were incubated for $3 \mathrm{~h}$ in serum-free OptiMEM medium at $37{ }^{\circ} \mathrm{C}$ with ligands at the indicated concentrations. Luciferase activity was visualized as previously described $[18,75]$.

\section{DMR assay}

DMR assays were performed as previously described [21, 49,
76]. In brief, $48 \mathrm{~h}$ before the assay, HEK-CB 2 R/GPR55 cells were seeded at a density of 7500 cells per well in 384-well Epic sensor microplates with $30 \mu \mathrm{l}$ growth medium (DMEM, 10\% FCS) and cultured for $24 \mathrm{~h}\left(37{ }^{\circ} \mathrm{C}, 5 \% \mathrm{CO}_{2}\right)$. Cells were serum starved in $30 \mu 1$ of starvation medium (Hank's buffered salt solution (HBSS) with $20 \mathrm{mM}$ HEPES, $\mathrm{pH} 7.15$ ) for $24 \mathrm{~h}$. Prior to the assay, cells were washed once with assay buffer (HBSS with 20 mM HEPES and $0.1 \%$ bovine serum albumin, fatty acid free (BSAfaf), $\mathrm{pH} 7.15$ ) and incubated in $30 \mu \mathrm{l}$ per well of assay-buffer in the Epic reader at $28{ }^{\circ} \mathrm{C}$. Hereafter, the sensor plate was scanned and a baseline optical signature was recorded. Ten $\mu l$ of ligands at indicated concentrations, dissolved in the assay buffer, were added to the cells and DMR responses were monitored for at least $3600 \mathrm{~s}$. The analysis of DMR data was performed as previously described [21, 49, 76]. Data were normalized and expressed as percent of maximum activation induced by concomitant addition of LPI and 2-AG.

\section{Microscopy and flow cytometry analysis}

Images were analyzed using an OLYMPUS fluorescence microscope equipped with a Hamamatsu ORCA CCD camera or a Zeiss LSM510 META Axioplan confocal microscope with PlanApochromat 1.4 Oil DIC objectives. Flow cytometry analyses were performed in a FACSCalibur flow cytometer (Becton Dickinson).

\section{Image and data analysis}

For quantification of active GTP-bound GTPases to total GTPase levels, data generated in at least three independent blots were analyzed using Image J software (NIH). Statistical analysis was performed using one-way ANOVA with Tukey post-test and $P$ values less than 0.05 were considered significant. GraphPad Prism Software, version 4.03 (GraphPad Software, Inc.) was used for these analyses.

\section{Acknowledgments}

We express our gratitude to J Silvio Gutkind and Hiroshi Yagi (National Institutes of Health, Bethesda, USA), Jennifer L Whistler (University of California San Francisco, USA) for reagents and to Julian Gomez-Cambronero (Wright State University, USA) for sharing his protocols for handling of HL60 cells. Special thanks go to the Heinemann-Lab, Rudolf Schicho and Rufina Schuligoi (Medical University of Graz, Austria) for valuable discussions. This work was supported by grants from the Austrian Science Fund (P18723 to MW; P19424 and P22521 to AH), the Jubiläumsfonds of the Austrian National Bank and the Lanyar Stiftung Graz (all to MW), the 'Molecular Medicine Ph.D. program' from the Medical University of Graz, Austria and a BaCa Visiting Scientists program (all to NABB, EA and JK). We would like to thank Corning Life Sciences for their support on the Epic ${ }^{\circledR}$ System.

\section{References}

1 Chakravarti A, Allaeys I, Poubelle PE. Neutrophils and immunity: is it innate or acquired? Med Sci (Paris) 2007; 23:862867.

2 Nathan C. Neutrophils and immunity: challenges and opportunities. Nat Rev Immunol 2006; 6:173-182.

3 Witko-Sarsat V, Rieu P, scamps-Latscha B, Lesavre P, Hal- 
bwachs-Mecarelli L. Neutrophils: molecules, functions and pathophysiological aspects. Lab Invest 2000; 80:617-653.

4 Luster AD, Alon R, von Andrian UH. Immune cell migration in inflammation: present and future therapeutic targets. Nat Immunol 2005; 6:1182-1190.

5 Monk PN, Scola AM, Madala P, Fairlie DP. Function, structure and therapeutic potential of complement $\mathrm{C} 5 \mathrm{a}$ receptors. Br J Pharmacol 2007; 152:429-448.

6 Premack BA, Schall TJ. Chemokine receptors: gateways to inflammation and infection. Nat Med 1996; 2:1174-1178.

7 Di M, V, Bisogno T, De PL, et al. Biosynthesis and inactivation of the endocannabinoid 2-arachidonoylglycerol in circulating and tumoral macrophages. Eur J Biochem 1999; 264:258-267.

8 Gauthier KM, Baewer DV, Hittner S, et al. Endothelium-derived 2-arachidonylglycerol: an intermediate in vasodilatory eicosanoid release in bovine coronary arteries. Am J Physiol Heart Circ Physiol 2005; 288:H1344-H1351.

9 Buckley NE. The peripheral cannabinoid receptor knockout mice: an update. Br J Pharmacol 2008; 153:309-318.

10 Munro S, Thomas KL, Abu-Shaar M. Molecular characterization of a peripheral receptor for cannabinoids. Nature 1993; 365:61-65.

11 Sugiura T, Kondo S, Kishimoto S, et al. Evidence that 2-arachidonoylglycerol but not N-palmitoylethanolamine or anandamide is the physiological ligand for the cannabinoid CB2 receptor. Comparison of the agonistic activities of various cannabinoid receptor ligands in HL-60 cells. J Biol Chem 2000; 275:605-612.

12 Kishimoto S, Gokoh M, Oka S, et al. 2-arachidonoylglycerol induces the migration of HL-60 cells differentiated into macrophage-like cells and human peripheral blood monocytes through the cannabinoid CB2 receptor-dependent mechanism. J Biol Chem 2003; 278:24469-24475.

13 Zhao Q, He Z, Chen N, et al. 2-Arachidonoylglycerol stimulates activator protein-1-dependent transcriptional activity and enhances epidermal growth factor-induced cell transformation in JB6 P+ cells. J Biol Chem 2005; 280:26735-26742.

14 Kurihara R, Tohyama Y, Matsusaka S, et al. Effects of peripheral cannabinoid receptor ligands on motility and polarization in neutrophil-like HL60 cells and human neutrophils. J Biol Chem 2006; 281:12908-12918.

15 Ryberg E, Larsson N, Sjogren S, et al. The orphan receptor GPR55 is a novel cannabinoid receptor. Br J Pharmacol 2007; 152:1092-1101.

16 Sharir H, Abood ME. Pharmacological characterization of GPR55, a putative cannabinoid receptor. Pharmacol Ther 2010; 126:301-313.

17 Pietr M, Kozela E, Levy R, et al. Differential changes in GPR55 during microglial cell activation. FEBS Lett 2009; 583:2071-2076.

18 Henstridge CM, Balenga NA, Ford LA, et al. The GPR55 ligand L-alpha-lysophosphatidylinositol promotes RhoA-dependent $\mathrm{Ca} 2+$ signaling and NFAT activation. FASEB J 2009; 23:183-193.

19 Lauckner JE, Jensen JB, Chen HY, et al. GPR55 is a cannabinoid receptor that increases intracellular calcium and inhibits M current. Proc Natl Acad Sci USA 2008; 105:2699-2704.

20 Kapur A, Zhao P, Sharir H, et al. Atypical responsiveness of the orphan receptor GPR55 to cannabinoid ligands. J Biol Chem 2009; 284:29817-29827

21 Henstridge CM, Balenga NA, Schroder R, et al. GPR55 ligands promote receptor coupling to multiple signaling pathways. Br J Pharmacol 2010; 160:604-614.

22 Oka S, Nakajima K, Yamashita A, Kishimoto S, Sugiura T. Identification of GPR55 as a lysophosphatidylinositol receptor. Biochem Biophys Res Commun 2007; 362:928-934.

23 Oka S, Toshida T, Maruyama K, et al. 2-Arachidonoyl-snglycero-3-phosphoinositol: a possible natural ligand for GPR55. J Biochem 2009; 145:13-20.

24 Corda D, Iurisci C, Berrie CP. Biological activities and metabolism of the lysophosphoinositides and glycerophosphoinositols. Biochim Biophys Acta 2002; 1582:52-69.

25 Falasca M, Iurisci C, Carvelli A, Sacchetti A, Corda D. Release of the mitogen lysophosphatidylinositol from H-Rastransformed fibroblasts; a possible mechanism of autocrine control of cell proliferation. Oncogene 1998; 16:2357-2365.

26 Falasca M, Corda D. Elevated levels and mitogenic activity of lysophosphatidylinositol in k-ras-transformed epithelial cells. Eur J Biochem 1994; 221:383-389.

27 Klein TW. Cannabinoid-based drugs as anti-inflammatory therapeutics. Nat Rev Immunol 2005; 5:400-411.

28 Varga K, Wagner JA, Bridgen DT, Kunos G. Platelet- and macrophage-derived endogenous cannabinoids are involved in endotoxin-induced hypotension. FASEB J 1998; 12:10351044.

29 Zoeller RA, Wightman PD, Anderson MS, Raetz CR. Accumulation of lysophosphatidylinositol in RAW 264.7 macrophage tumor cells stimulated by lipid A precursors. $J$ Biol Chem 1987; 262:17212-17220.

30 Emilsson A, Sundler R. Differential activation of phosphatidylinositol deacylation and a pathway via diphosphoinositide in macrophages responding to zymosan and ionophore A23187. J Biol Chem 1984; 259:3111-3116.

31 McHugh D, Tanner C, Mechoulam R, Pertwee RG, Ross RA. Inhibition of human neutrophil chemotaxis by endogenous cannabinoids and phytocannabinoids: evidence for a site distinct from CB1 and CB2. Mol Pharmacol 2008; 73:441-450.

32 Steffens S, Veillard NR, Arnaud C, et al. Low dose oral cannabinoid therapy reduces progression of atherosclerosis in mice. Nature 2005; 434:782-786.

33 Jorda MA, Verbakel SE, Valk PJ, et al. Hematopoietic cells expressing the peripheral cannabinoid receptor migrate in response to the endocannabinoid 2-arachidonoylglycerol. Blood 2002; 99:2786-2793.

34 Walter L, Franklin A, Witting A, et al. Nonpsychotropic cannabinoid receptors regulate microglial cell migration. $J \mathrm{Neu}$ rosci 2003; 23:1398-1405.

35 Oka S, Ikeda S, Kishimoto S, et al. 2-arachidonoylglycerol, an endogenous cannabinoid receptor ligand, induces the migration of EoL-1 human eosinophilic leukemia cells and human peripheral blood eosinophils. J Leukoc Biol 2004; 76:1002-1009.

36 Springer TA. Traffic signals for lymphocyte recirculation and leukocyte emigration: the multistep paradigm. Cell 1994; 76:301-314.

37 Bokoch GM. Regulation of innate immunity by Rho GTPases. Trends Cell Biol 2005; 15:163-171. 
38 Carstanjen D, Yamauchi A, Koornneef A, et al. Rac2 regulates neutrophil chemotaxis, superoxide production, and myeloid colony formation through multiple distinct effector pathways. J Immunol 2005; 174:4613-4620.

39 Diebold BA, Fowler B, Lu J, Dinauer MC, Bokoch GM. Antagonistic cross-talk between Rac and Cdc42 GTPases regulates generation of reactive oxygen species. $J$ Biol Chem 2004; 279:28136-28142.

40 Ford LA, Roelofs AJ, navi-Goffer S, et al. A role for L-alphalysophosphatidylinositol and GPR55 in the modulation of migration, orientation and polarization of human breast cancer cells. Br J Pharmacol 2010; 160:762-771.

41 Whyte LS, Ryberg E, Sims NA, et al. The putative cannabinoid receptor GPR55 affects osteoclast function in vitro and bone mass in vivo. Proc Natl Acad Sci USA 2009; 106:1651116516.

42 Maestroni GJ. The endogenous cannabinoid 2-arachidonoyl glycerol as in vivo chemoattractant for dendritic cells and adjuvant for Th1 response to a soluble protein. FASEB J 2004; 18:1914-1916.

43 Smith DM, Waite M. Phosphatidylinositol hydrolysis by phospholipase A2 and C activities in human peripheral blood neutrophils. J Leukoc Biol 1992; 52:670-678.

44 Zhelev DV, Alteraifi A. Signaling in the motility responses of the human neutrophil. Ann Biomed Eng 2002; 30:356-370.

45 Bouaboula M, Rinaldi M, Carayon P et al. Cannabinoid-receptor expression in human leukocytes. Eur J Biochem 1993; 214:173-180.

46 Galiegue S, Mary S, Marchand J, et al. Expression of central and peripheral cannabinoid receptors in human immune tissues and leukocyte subpopulations. Eur J Biochem 1995; 232:54-61.

47 Miller AM, Stella N. CB2 receptor-mediated migration of immune cells: it can go either way. Br J Pharmacol 2008; 153:299-308.

48 Waldeck-Weiermair M, Zoratti C, Osibow K, et al. Integrin clustering enables anandamide-induced $\mathrm{Ca} 2+$ signaling in endothelial cells via GPR55 by protection against CB1-receptortriggered repression. J Cell Sci 2008; 121:1704-1717.

49 Schroder R, Janssen N, Schmidt J, et al. Deconvolution of complex $\mathrm{G}$ protein-coupled receptor signaling in live cells using dynamic mass redistribution measurements. Nat Biotechnol 2010; 28:943-949.

50 Baggiolini M. Chemokines and leukocyte traffic. Nature 1998; 392:565-568.

51 Van KA, Wong K, Knight ZA, et al. To stabilize neutrophil polarity, PIP3 and Cdc42 augment RhoA activity at the back as well as signals at the front. J Cell Biol 2006; 174:437-445.

52 Quinn MT, Gauss KA. Structure and regulation of the neutrophil respiratory burst oxidase: comparison with nonphagocyte oxidases. J Leukoc Biol 2004; 76:760-781.

53 Dong X, Mo Z, Bokoch G, et al. P-Rex1 is a primary Rac2 guanine nucleotide exchange factor in mouse neutrophils. Curr Biol 2005; 15:1874-1879.

54 Welch HC, Condliffe AM, Milne LJ, et al. P-Rex1 regulates neutrophil function. Curr Biol 2005; 15:1867-1873.

55 Mitchell T, Lo A, Logan MR, Lacy P, Eitzen G. Primary granule exocytosis in human neutrophils is regulated by Racdependent actin remodeling. Am J Physiol Cell Physiol 2008;
295:C1354-C1365.

56 Foxman EF, Kunkel EJ, Butcher EC. Integrating conflicting chemotactic signals. The role of memory in leukocyte navigation. J Cell Biol 1999; 147:577-588.

57 Ridley AJ, Schwartz MA, Burridge K, et al. Cell migration: integrating signals from front to back. Science 2003; 302:1704-1709.

58 Wong K, Van KA, Bourne HR. PDZRhoGEF and myosin II localize RhoA activity to the back of polarizing neutrophillike cells. J Cell Biol 2007; 179:1141-1148.

$59 \mathrm{Xu}$ J, Wang F, Van KA, et al. Divergent signals and cytoskeletal assemblies regulate self-organizing polarity in neutrophils. Cell 2003; 114:201-214.

60 Oka S, Kimura S, Toshida T, et al. Lysophosphatidylinositol induces rapid phosphorylation of p38 mitogen-activated protein kinase and activating transcription factor 2 in HEK293 cells expressing GPR55 and IM-9 lymphoblastoid cells. $J$ Biochem 2010; 147:671-678.

61 Glass M, Northup JK. Agonist selective regulation of G proteins by cannabinoid $\mathrm{CB}(1)$ and $\mathrm{CB}(2)$ receptors. Mol Pharmacol 1999; 56:1362-1369.

62 Jbilo O, Derocq JM, Segui M, Le FG, Casellas P. Stimulation of peripheral cannabinoid receptor $\mathrm{CB} 2$ induces $\mathrm{MCP}-1$ and IL-8 gene expression in human promyelocytic cell line HL60. FEBS Lett 1999; 448:273-277.

63 Abdel-Latif D, Steward M, Macdonald DL, et al. Rac2 is critical for neutrophil primary granule exocytosis. Blood 2004; 104:832-839.

64 Koh AL, Sun CX, Zhu F, Glogauer M. The role of Rac1 and Rac2 in bacterial killing. Cell Immunol 2005; 235:92-97.

65 Ridley AJ, Paterson HF, Johnston CL, Diekmann D, Hall A. The small GTP-binding protein rac regulates growth factorinduced membrane ruffling. Cell 1992; 70:401-410.

66 Kozma R, Ahmed S, Best A, Lim L. The Ras-related protein $\mathrm{Cdc} 42 \mathrm{Hs}$ and bradykinin promote formation of peripheral actin microspikes and filopodia in Swiss 3T3 fibroblasts. Mol. Cell Biol 1995; 15:1942-1952.

67 Rosenfeldt H, Castellone MD, Randazzo PA, Gutkind JS. Rac inhibits thrombin-induced Rho activation: evidence of a Pakdependent GTPase crosstalk. J Mol Signal 2006; 1:8.

68 Nimnual AS, Taylor LJ, Bar-Sagi D. Redox-dependent downregulation of Rho by Rac. Nat Cell Biol 2003; 5:236-241.

69 Zhang B, Zheng Y. Negative regulation of Rho family GTPases Cdc42 and Rac2 by homodimer formation. J Biol Chem 1998; 273:25728-25733.

70 Gomez-Cambronero J, Frye T, Baumann M. Ribosomal p70S6K basal activity increases upon induction of differentiation of myelomonocytic leukemic cell lines HL60, AML14 and MPD. Leuk Res 2004; 28:755-762.

71 Pfaffl MW. A new mathematical model for relative quantification in real-time RT-PCR. Nucleic Acids Res 2001; 29:e45.

72 Schratl P, Heinemann A. Differential involvement of Ca2+ and actin filament in leukocyte shape change. Pharmacology 2009; 83:131-140.

73 Sturm EM, Schratl P, Schuligoi R, et al. Prostaglandin E2 inhibits eosinophil trafficking through E-prostanoid 2 receptors. J Immunol 2008; 181:7273-7283.

74 Tan W, Martin D, Gutkind JS. The Galpha13-Rho signaling axis is required for SDF-1-induced migration through 
CXCR4. J Biol Chem 2006; 281:39542-39549.

75 Waldhoer M, Kledal TN, Farrell H, Schwartz TW. Murine cytomegalovirus (CMV) M33 and human CMV US28 receptors exhibit similar constitutive signaling activities. J Virol 2002; 76:8161-8168.
76 Schroder R, Merten N, Mathiesen JM, et al. The C-terminal tail of CRTH2 is a key molecular determinant that constrains Galphai and downstream signaling cascade activation. J Biol Chem 2009; 284:1324-1336.

(Supplementary information is linked to the online version of the paper on the Cell Research website.) 